RIK VAN WELIE

\title{
SLAVE TRADING AND SLAVERY IN THE DUTCH COLONIAL EMPIRE: A GLOBAL COMPARISON
}

\section{INTRODUCTION}

From the early seventeenth to the mid-nineteenth century, slavery played a fundamental role in the Dutch colonial empire. ${ }^{1}$ All overseas possessions of the Dutch depended in varying degrees on the labor of slaves who were imported from diverse and often remote areas. Over the past decades numerous academic publications have shed light on the history of the Dutch Atlantic slave trade and of slavery in the Dutch Americas. ${ }^{2}$ These scholarly contributions, in combination with the social and political activism of the descendants of Caribbean slaves, have helped to bring the subject of slavery into the national public debate. The ongoing discussions about an official apology for the Dutch role in slavery, the erection of monuments to commemorate that history, and the inclusion of some of these topics in the first national history canon are all testimony to this increased attention for a troubled past. ${ }^{3}$ To some this recent focus on the negative aspects of Dutch colonial history has already gone too far, as they summon the country's glorious past to instill a

1. I would like to thank David Eltis, Pieter Emmer, Henk den Heijer, Han Jordaan, Gerrit Knaap, Gert Oostindie, Alex van Stipriaan, Jelmer Vos, and the anonymous reviewers of the New West Indian Guide for their many insightful comments. As usual, the author remains entirely responsible for any errors. This article is an abbreviated version of a chapter written for the "Migration and Culture in the Dutch Colonial World" project at KITLV. Readers interested in a fuller discussion of Dutch colonial slavery in the VOC domain, as well as a more extensive list of relevant sources, should consult Van Welie forthcoming.

2. This historiography is far too extensive to warrant mentioning here. A few recent works representing the major scholars in the field that are used here are Postma 1990, Van Stipriaan 1993, Oostindie 1995, Den Heijer 1997, Klooster 1997, Emmer 2000, Jordaan 2003.

3. See Oostindie 1999, 2008 for some insightful readings on this current struggle with the Dutch slavery past.

New West Indian Guide / Nieuwe West-Indische Gids vol. 82 no. 1 \& 2 (2008):47-96 
new sense of pride and patriotism - instead of political correctness - in the Dutch. ${ }^{4}$ And while the Dutch premier Jan Peter Balkenende should perhaps be given the benefit of the doubt for his call for a return to the "VOC mentality" - after all, there were plenty of inspiring aspects to the history of the Dutch East India Company (VOC) - it nevertheless demonstrated a lack of tact and historical understanding. ${ }^{5}$

This continued admiration for the VOC signals that the Dutch historical imagination still connects most negative aspects of colonialism with the history of the West India Company (WIC) and its Caribbean possessions. That slavery also played a prominent role in the VOC domain has seemingly been forgotten. This public ignorance merely reflects the state of academic scholarship on the subject. Slavery has never been a fashionable topic among historians of the VOC, and its general absence in the literature is not an exclusively Dutch phenomenon either. In fact, the historiography of Indian Ocean World slavery in general is still in an embryonic stage. Fortunately, propelled by the recent efforts of a small number of historians, we are learning more about the nature of European colonial slavery in the East and can begin, in the words of one of these scholars, "to 'unsilence' this part of our history and 're-Orient' the historiographical imbalance" in slavery studies (Vink 2003:135). ${ }^{6}$

Whenever the topic of slavery is discussed in contemporary society, an instinctively defensive reaction has been to claim that it was always a natural and widely accepted institution among human beings, and that even the tolerant Dutch were unaware of its moral wrongs until the abolitionist movement emerged in the late eighteenth century. A closer look, however, reveals that argumentation is deceiving at best. First of all, the early modern Dutch - and

4. Dutch politician Rita Verdonk's inaugural speech (April 3, 2008) for her political movement Trots op Nederland (TON, "Proud of the Netherlands"), lamented the presence of an anti-Dutch culture in the Netherlands which "seeks to erect slave monuments all over the place in order to depict us as evil." The fact that she, as a cabinet minister (of immigration), was verbally harassed at a commemoration at the national slavery monument in Amsterdam a few years earlier may have influenced these remarks.

5. Premier Balkenende made these ill-advised comments during the Algemene Beschouwingen in Dutch parliament on September 28, 2006. He does not of course stand alone in this celebratory attitude regarding the history of the VOC; see Van Stipriaan \& Bal 2002 and Oostindie 2003 for critical commentary on the uncritical public commemoration of the 400-year anniversary of the founding of the VOC.

6. The major historians working on slavery in the Indian Ocean World are well represented in the general overviews of Reid 1983 and Campbell 2004a, 2004b, while Knaap 1981, 1991, 1995, Vink 2003, and, most recently, Raben 2008 have focused more specifically on the Dutch role in it. Vink's comment about "historiographical imbalance" is particularly interesting in light of the general view among historians of Dutch colonialism, namely that the Dutch Americas have often been neglected in favor of the more celebrated history of the VOC. This proves even more that when it comes to the study of colonial slavery, attention has almost completely been centered on the New World. 
with them most other Europeans - no longer deemed it morally acceptable to enslave fellow Europeans. Apparently, slave status was only fitting for people of African or Asian descent. ${ }^{7}$ Secondly, while outsiders were still eligible to become slaves, as an institution slavery had almost completely disappeared from the Dutch Republic and selected other parts of Western Europe and would not return, even though an official moment of abolition eludes us. ${ }^{8}$ Historians have often been struck by this curious paradox: that the seventeenth-century Dutch took great pride in their hard-fought freedom and climate of tolerance at home, while simultaneously employing hundreds of thousands of slaves in their overseas dominions (Eltis 1993, 1999, Drescher 1994).

But perhaps this paradox holds the explanation as to why the public awareness of slavery in Dutch history has until recently been so limited. In sharp contrast with most other lucrative commodities bought and sold by the merchants of the VOC and the WIC, slaves seldom passed through the Dutch Republic. The trade in slaves, even then considered an "uncommon market" (Gemery \& Hogendorn 1979), was always held at a relatively comfortable distance. And whenever this physical distance was occasionally bridged, like in the frequently cited Middelburg case of 1596, the Dutch commitment to freedom was instantly tested. ${ }^{9}$ Colonists returning to their homeland were generally prohibited from taking their slaves along and, when doing so anyway, risked the loss of their property by implicit manumission. David Brion Davis (2000:458), the eminent historian of Western slavery, spoke of these moral and legal boundaries as "primitive 'Mason-Dixon' lines, now drawn somewhere in the Atlantic, separating free soil master-states from tainted slave soil

7. Initial experiments with Native American slaves were quickly aborted because of a lack of success.

8. There is sparse evidence suggesting the presence of African and Asian slaves in the Low Countries from the sixteenth to the eighteenth centuries, but it is almost entirely drawn from the commercial juggernauts of Antwerp and Amsterdam, global ports with strong connections to overseas colonies. Our understanding of this "metropolitan slavery" is still scanty, partly because of the scarcity of the source material, the numbers cannot have been very high, partly because the line dividing slave from servant appears rather blurred here, if not de jure then certainly de facto. Slaves brought back on return voyages from the colonies - generally considered an illegal practice - were often manumitted on arrival in the Netherlands and became personal servants, with their daily tasks arguably differing very little from those serving as domestic slaves in the colonies. As a cultural theme, slaves, especially young children, figured prominently in early modern paintings of wealthy burghers. See Oostindie \& Maduro 1986 and Blakely 1993 for the African presence in the Dutch Republic.

9. In 1596 a ship carrying 130 Angolan slaves, most likely captured at sea from the Portuguese enemy, entered the province of Zeeland with the intention of selling this human cargo for profit on the local market. However, these plans were, as far as we can tell from the available documentation, prevented by the protests from several concerned citizens. 
dependencies."10 Because of this physical and psychological separation, there was hardly any need to come to terms with colonial slavery in the metropolis.

How much more direct is the awareness in the United States, or most other former colonies in the Americas, where slavery had been planted in its very midst and functioned as a foundational theme in the national history? With the descendants of slaves visibly and ever more vocally present, citizens could not afford the luxury of ignoring an ignoble past. It may perhaps not come as a surprise that until this very day many Europeans, when confronted with the topic of slavery, still conjure up a Hollywood-type image of black slaves picking cotton in the antebellum South as if it was an exclusively American invention. ${ }^{11}$

There is, in my opinion, no better strategy for emphasizing the Dutch role in colonial slave trading and slavery than by summing up the hard facts of this history. In this article I will present the latest quantitative assessments concerning the Dutch transatlantic slave trade, making ample use of an important modern database, ${ }^{12}$ but also place the volume and directions of this forced migration in a historical context. Subsequently, I will briefly sketch an outline of the heavily underresearched slave trade in the VOC domain, thereby providing a comparative framework for the Atlantic slave trade as well as problematizing our rather one-sided focus on slavery in the Americas. Finally, a global comparison of colonial slavery may help explain why slavery and race relations in the Dutch colonial empire developed as they did. I realize that parts of this article fall outside the scope of Caribbean history, yet hope readers may nevertheless profit from a broader perspective by looking afresh at their own specialized field of research. ${ }^{13}$ After all, no one had to

10. Sue Peabody 1997 has given a masterful historical analysis of this paradox in early modern France and its colonies. Recently, Susan Amussen 2007 explored how English metropolitan society came to terms with colonial slavery during the seventeenth century. The "Mason-Dixon line" separated the free northern territories of the United States from the slave states of the South.

11. This traditional overemphasis on slavery in the antebellum U.S. South is, undoubtedly, a result of the powerful influence of the African American civil rights movement of the 1950s and 1960s and the popular portrayal of history by Hollywood. But in a sense, the European fascination with U.S. slavery dates back to its portrayal in Harriet Beecher Stowe's classic Uncle Tom's Cabin, or Life among the Lowly (1852).

12. David Eltis et al. (eds.), The Trans-Atlantic Slave Trade: A Database on CD-Rom (Cambridge: Cambridge University Press). Henceforth "TDST."

13. Most comparative histories of slavery remain confined to the Americas, but some outstanding exceptions are that of Frederickson 1981 who compared slavery and racism in the settlement colonies of North America and South Africa, and Kolchin 1987, although his comparison moved beyond slavery to include Russian serfdom. Pétré-Grenouilleau 2004 discusses the European and Arabian slave trades together, while Christopher et al. 2007 takes an even broader look at forced migrations. Daalder et al. 2001 focuses on Dutch colonial slavery and slave trading across the globe. 
explain to Dutch Surinamers that lauding the "VOC mentality" could possibly be construed as offensive to them.

\section{QUANTIFying The TRAnSATLANTIC Slave TRADE}

The transatlantic slave trade was a remarkably straightforward and onedirectional migration, the key component of an ingenious triangular commercial system that has been well documented. Ships loaded with a carefully selected assortment of products sailed from diverse ports in Western Europe to the West African coast, where European merchants exchanged these commodities for African slaves sold by local traders; the human cargo was then transported to strategic locations in the Americas, before returning home carrying slave-produced commodities such as sugar, coffee, and tobacco to the European market. It was a good example of the emergence of global trade in the early modern period. If the voyage went as planned, and this included keeping slave mortality on board to a minimum, investors stood to profit from several transactions.

For the African victims the Middle Passage was merely one part of their tragic journey to the Americas. First, they experienced enslavement, coerced transportation, and confinement in Africa itself, before being sold to what must have seemed strange white men who subsequently moved them under excruciating circumstances across the Atlantic Ocean. Finally, after disembarking in the Americas, they often faced further regional trading and transport. For the great majority of them, backbreaking labor on large commercial plantations under the tropical sun loomed as the final destination. The forced alienation of those who survived this initial ordeal - the aggregated mortality rate must have been considerably higher than the estimated 14.5 percent for the transatlantic crossing alone ${ }^{14}$ - undeniably impacted their identity: from local or tribal affiliations within Africa to a more diffuse African identity versus the Europeans on board and, with the passage of time, to the birth of uniquely African American slave cultures. ${ }^{15}$

14. The estimated mortality rate is based on the current version of the "Trans-Atlantic Slave Trade Database" (TSTD2). It should be added here that very high mortality rates applied to the European crew of the slave ships as well, primarily because of the unhealthy tropical conditions on the African coast, where ships could experience long waiting periods before setting sail for the Americas.

15. The scholarly debate on creolization is an important one, and a good place to start is the classic statement by Sidney Mintz and Richard Price 1992. To emphasize the important role of the transatlantic slave trade in fostering creolization, the cover of their book shows the famous abolitionist sketch of slaves crammed into a British ship during the Middle Passage. For a more recent assessment of the concept, see Price 2006. 
Depicting this forced migration in broad dramatic strokes is far easier than charting its precise directions in time and space. To pinpoint the exact origination of the slaves in Africa on the one hand - the so-called provenance zones or "catchment" areas - one needs to be well-versed in regional African history, where primary evidence is often deficient. Establishing the specific end destinations in the Americas on the other hand, requires a deep understanding of multiple colonial histories. Furthermore, the records left of slave-ship voyages themselves and their actual embarkation and disembarkation ports are vast, yet still far from complete. It may not come as a surprise that African Americans with the desire and means to uncover their genealogy are currently putting more faith in the scientific path of modern DNA research. ${ }^{16}$

Due to its highly organized and businesslike character, with slave embarkation, mortality, and disembarkation being meticulously registered, historians have been left with large amounts of administrative evidence from which the business, volume, and direction of the transatlantic slave trade can be reconstructed. They have been mainly occupied with three research objectives: first, the "numbers game," or closely estimating the volume of slaves traded, transported, and having perished along the way; second, determining which European nations were involved in slave trading and to what degree; and, finally, establishing which specific African groups fell victim to this forced migration and where and how their lives and cultures in the Americas continued. The first modern quantitative overview of the Atlantic slave trade by Philip Curtin (1969) inspired many historians to conduct empirical research in archival depositories. Eventually, the various cliometric data sets that emerged from this were combined into the "Trans-Atlantic Slave Trade Database," an ongoing and truly collaborative project of a global community of scholars. ${ }^{17}$ The current version of the database (TSTD2) contains a total of 34,850 registered slave voyages between 1501 and 1866, and based on these records estimates that around 12,521,300 slaves left Africa with about 10,702,700 making it to the Americas. These modern estimates are only slightly above the total numbers Curtin proposed almost four decades ago, but they are now corroborated by a wealth of supporting evidence. ${ }^{18}$

16. This kind of research has become especially popular in the United States, where celebrities like Oprah Winfrey have given it ample attention. In the Netherlands, Alex van Stipriaan is currently doing research on this topic.

17. Work on the TSTD dates back to the 1980s, when computer and database technologies were still rather limited. For the first officially published version was by Eltis et al. 1999. The new and improved dataset, TSTD2, is an online version, and will become interactive and accessible to the general public in 2008. It is a revolutionary project aimed at bringing professional research and public education closer together.

18. Curtin (1969:87) had revised previous import estimates downward stating that "it is extremely unlikely that the ultimate total will turn out to be less than $8,000,000$ or more than 10,500,000." 
Table 1 gives a general overview of the volume of the transatlantic slave trade, broken down by century and European carrier.

Table 1 Estimated African slave exports by national carrier, 1501-1866*

\begin{tabular}{lrrrrr}
\hline & $1501-1600$ & $1601-1700$ & $1701-1800$ & $1801-1866$ & \multicolumn{1}{c}{ Total } \\
\hline Spain/Uruguay & 120,000 & 146,300 & 10,700 & 784,600 & $1,061,600$ \\
Portugal/Brazil & 154,200 & $1,011,200$ & $2,213,000$ & $2,468,900$ & $5,848,300$ \\
Great Britain & 1,900 & 428,300 & $2,545,300$ & 284,000 & $3,259,400$ \\
Netherlands & 1,400 & 219,900 & 330,000 & 3,000 & 554,300 \\
United States** & & 4,200 & 189,300 & 111,900 & 305,300 \\
France & 100 & 38,400 & $1,139,000$ & 203,900 & $1,381,400$ \\
Denmark/Baltic & & 27,400 & 67,300 & 16,300 & 111,000 \\
Total & 277,500 & $1,875,600$ & $6,494,600$ & $3,873,600$ & $12,521,300$ \\
\hline
\end{tabular}

Source: TSTD; www.slavevoyages.com, www.slavevoyages.org; (http://wilson.library.emory.edu:9090/tast/assessment/estimates.faces?permlink=1788875).

* For purposes of calculation, estimates of embarked and disembarked slaves in TSTD2 have not been rounded off. To prevent reading these numbers as precise totals, I have rounded the estimates off to the nearest hundred; because I have done so with the aggregated "totals" as well, they may not always be the exact sum of the individual estimates in these tables.

** The database assigns slave voyages that were organized and departed from colonial North America in the seventeenth and eighteenth centuries (mainly Rhode Island) to what would later become the United States.

At the present the database contains 1,237 officially documented Dutch slave voyages with a total of 408,658 slaves departing from Africa. Through elaborate, but by no means flawless, methods these data are extrapolated to an estimated total of 554,300 slaves exported by the Dutch or roughly 4.4 percent of the overall volume of the transatlantic slave trade. And of these slaves around 475,200 reached the Americas alive (a mortality rate of 14.3 percent). These figures are fairly close to what the classic account of the Dutch Atlantic slave trade proposes (Postma 1990:295), which makes perfect sense, as the database relies heavily on the primary research by Johannes Postma. ${ }^{19}$ Recently, Postma (2003a:137) downgraded his own assessments quite substantially to 501,409 slaves exported or 4.6 percent of the total trade, with an annual average of 2,458 slaves embarking on the African coast. ${ }^{20}$

19. Although the parameters are slightly different, estimating 542,972 slaves exported from Africa in the period 1600-1803 (Postma 1990:295). Postma has been working on the Dutch Atlantic slave trade since the 1960s, when he wrote his dissertation at Michigan State University, and acknowledges being influenced by Curtin's landmark study at the time (Postma 2003a:118-19).

20. Postma's revisions lower his previous estimates by 7 percent and the Dutch share of the entire transatlantic slave traffic from 4.7 percent to 4.6 percent. He is, in my opinion, rather harsh on himself, calling the reassessment "a humbling experience" showing "that 
Based on new empirical research by fellow historians, Postma now believes that a large number (207) of eighteenth-century voyages to Africa, ones he previously assumed to be slave voyages, were actually bilateral commodity traders returning directly to Europe. He thus changed from a "maximalist" approach, "wanting to make certain the volume of the slave trade was not understated," to a "minimalist" one, "including only those ships for which there is clear evidence that they carried slaves" (Postma 2003a:129).

The compilers of the TSTD2, after incorporating the data collected by Postma, Den Heijer, and several others, make "slightly more aggressive assumptions" and argue, for example, that very few Dutch vessels sailing to the Angola region went there to trade in produce only (Vos, Eltis \& Richardson forthcoming). And when Postma (2003a:121) decides to leave out approximately 3,000 slaves captured from Dutch ships "because they were presumably disembarked in the Americas by ships of other nations," TSTD2 still assigns those to the Dutch slave trade based on their original African departure. Such quibbles are exemplary of the many judgment calls historians are forced to make in order to cope with gaps in the historical records and with evidence that defies easy categorization. For example, a recent dissertation (Paesie 2008) argues for a substantial increase in the volume of the Dutch slave trade based on hundreds of illicit slave voyages originating from the Dutch Republic, primarily from the maritime province of Zeeland. However, quite a few of these interlopers sailed - partly to escape the harsh WIC reprisals - under foreign flags. Based on this, TSTD2 would qualify these voyages under other European states even though it is fairly clear that these were predominantly Dutch-led operations. Working with a modern database fortunately allows the researcher some flexibility to adjust such marginal cases according to his or her personal preferences. But the decisive factor in establishing the nationality of a slave voyage - the investors, the owner of the vessel, the captain and crew, the flag - will likely remain elusive. Breaking down the transatlantic slave trade by national background therefore remains a complex and subjective exercise.

Despite the inherent subjectivity of all assumptions, extrapolations, and estimations involved, historians generally agree that slightly more than half a million Africans were transported on Dutch ships, with somewhere between 50,000 to 100,000 slaves perishing before they reached the New World. ${ }^{21}$ While research on specific periods and aspects of the trade will likely continue,

assumptions and speculation, however reasonable they may seem, are always inferior to verifiable evidence" (Postma 2003a:137). Note furthermore that Postma's estimate for the Dutch trade is lower in absolute numbers, but higher in its relative share of the total trade compared to TSTD2, suggesting that he still uses a significantly lower estimate (TSTD1?) for the total volume of the transatlantic slave trade.

21. Once again, Curtin's guesstimates were remarkably close to the mark: "While a reliable estimate is not possible from the present literature, 500,000 is accepted here for 
any dramatic alterations to this general picture need no longer be expected. With regard to sheer volume, the Dutch are regarded as a second-rate player in the transatlantic slave trade, certainly important, yet not comparable to the massive numbers transported by Portuguese or British vessels.

Such grand total figures can sometimes be misleading, however, or at least conceal interesting historical patterns. For example, as Table 1 indicates, the Dutch were only truly active slavers during the seventeenth and eighteenth centuries, so if we limit our calculations to that period, their share of the total volume moves upward to 6.6 percent. The Dutch commanded an even stronger position during the seventeenth-century "Golden Age" (11.7 percent), and in the period 1650 to 1675 , more or less the age of the Caribbean sugar revolution, Dutch vessels were responsible for over 20 percent of the entire transatlantic slave trade. Thus, to properly understand the relative impact of the Dutch, one needs to place the aggregated totals in a specific historical context. The volume and direction of the Dutch transatlantic slave trade will therefore be situated in time and space, in a modest attempt to historicize and interpret some of the general data presented in Tables 2 and 3.

Table 2 Estimated Dutch slave exports per African region, 1596-1829

\begin{tabular}{lrrrrrr}
\hline & $1596-1650$ & $1651-1700$ & $1701-1750$ & $1751-1800$ & $1801-1829$ & Total \\
\hline Senegambia & & 8,400 & 400 & 400 & & 9,200 \\
Sierra Leone & & 800 & & 800 & 700 & 2,300 \\
Windward C. & 800 & 18,200 & 41,700 & 42,500 & 300 & 103,400 \\
Gold Coast & 5,400 & 71,300 & 47,500 & 2,700 & & 126,900 \\
Bight of Benin & 6,900 & 20,300 & 500 & 1,000 & 100 & 28,700 \\
Bight of Biafra & 21,900 & 67,400 & 53,400 & 61,100 & 900 & 204,800 \\
West Central Africa & 34,900 & 186,400 & 156,900 & 173,100 & 3,000 & 554,300 \\
Total & & & & & & \\
\hline
\end{tabular}

Source: "Trans-Atlantic Slave Trade Database" (TSTD2), www.slavevoyages.com; www.slavevoyages.org, (http:// wilson.library.emory.edu:9090/tast/assessment/estimates.faces?permlink=1788878).

When dealing with a sensitive subject such as slavery, quantitative studies are often criticized for being cold-hearted accounts, with the slaves amounting to little more than lifeless numbers on paper. ${ }^{22}$ This article could easily

the whole of Dutch America during the whole of the slave trade, including present-day Guyana" (1969:85).

22. This should hardly come as a surprise, since we are left with a wealth of data from the European trade records, several descriptive accounts from European witnesses to the slave trade, but with almost no authentic sources from the African or slave perspective. In the preface to his classic Philip Curtin (1969:xix) wrote: "Some readers may miss the sense of moral outrage traditional in histories of the trade. This book will have very little to say about the evils of the slave trade, still less in trying to assign retrospective blame to 
Table 3 Estimated Dutch slave imports per region, 1596-1829

\begin{tabular}{lcrrrrr}
\hline & $1596-1650$ & $1651-1700$ & $1701-1750$ & $1751-1800$ & $1801-1829$ & Total \\
\hline Europe & 100 & 1,900 & & & & 2,000 \\
North America & & 1,200 & & & & 1,200 \\
British Caribbean & 900 & 4,700 & 400 & 700 & 300 & 7,000 \\
French Caribbean & & 11,600 & 600 & 600 & & 12,700 \\
Danish Caribbean & & & 5,200 & & & 5,200 \\
Dutch Caribbean* & & 81,500 & 40,000 & 20,200 & & 141,700 \\
Dutch Guianas & & 34,000 & 84,300 & 130,200 & 1,800 & 250,300 \\
Dutch Brazil & 26,600 & 1,100 & & & & 27,700 \\
Spanish Americas & 1,300 & 17,800 & 3,300 & 1,400 & 400 & 24,200 \\
Africa & & 3,000 & & & 300 & 3,300 \\
Total & 28,800 & 156,800 & 133,700 & 153,100 & 2,800 & 475,300 \\
\hline
\end{tabular}

Source: TSTD2.

* Dutch Caribbean is used here in its narrow insular definition, while Suriname and the other Wild Coast settlements fall under the Dutch Guianas.

serve as a typical example of this. But while statistical tables and graphs cannot adequately describe the individual and collective human tragedies of the Middle Passage, they are nevertheless an unmistakable reflection of the bulk of source material historians are left with. ${ }^{23}$ Furthermore, recent publications have shown how a mastery of hard data can ultimately lead to excitingly fresh and culturally sensitive interpretations, or toward the debunking of them (Eltis 2000). The greatest challenge for future research will remain the exploration of the directional patterns of this forced mass migration, connecting specific provenance zones in Africa with their particular destinations in the Americas. Only then, for example, can historians and anthropologists make accurate observations about the cultural impact of the slaves on their respective New World settlements. ${ }^{24}$

the individuals or groups who were responsible. This omission in no way implies that the slave trade was morally neutral; it clearly was not. The evils of the trade, however, can be taken for granted as a point long since proven beyond dispute."

23. Recent studies focus on the treatment of slaves during the Middle Passage and particularly the relationship between the largely European crew and the African "cargo"; see Christopher 2006 and Rediker 2007.

24. Of course, research on African retention in the Americas is by no means new. As early as the 1920s and 1930s, Melville Herskovits studied the culture of the descendants of slaves and Maroons in Suriname, looking for specific African elements. The point is that with the aid of the TSTD such observations and assumptions can be cross-checked with our own empirical findings. 


\section{Historicizing THE DUTCH TRANSATLANTIC SLAVE TRADE}

Given that their commercial activities on the African coast dated back to the mid-1590s, the Dutch waited several decades before actively participating in the slave trade. Initially, Dutch African trade was primarily focused on gold and, to a much lesser extent, ivory. ${ }^{25}$ Their first official settlement on the African coast, Fort Nassau (1612) at Mouri on the Gold Coast, did not spark any serious slaving activities either. Perhaps this hesitation was caused by initial moral reservations regarding the traffic in humans or, more plausibly, can be attributed to the fact that the Dutch still lacked a suitable American colony with a strong demand for slave labor. ${ }^{26}$

As the rise of Dutch colonial expansion was closely tied to the enduring conflict with Spain (as well as with Portugal since 1580), Iberian shipping became fair game for Dutch privateers. The capture of Portuguese slave ships in and around the Atlantic Ocean resulted in what has been labeled an "incidental slave trade" (Emmer 1972b:728-29). Slaves carried by the enemy were defined as contraband and, when possible, sold to the nearest friendly buyer. ${ }^{27}$ The incidental slave trade reached a peak during the first full decade of the WIC, but the 2,356 slaves, if we accept WIC official Johannes de Laet's count, taken between 1623 and 1636 (Van den Boogaart \& Emmer 1979:355) were, despite their value as propaganda, rather insignificant from a quantitative perspective. ${ }^{28}$

25. For the relative importance of the gold and ivory trade in relation to the slave trade for the seventeenth-century Dutch on the African coast, see Van den Boogaart 1992 and the response by Eltis 1994. By around 1615 the Portuguese were complaining to the Spanish king that the Dutch dominated all African trades, except for the one in slaves (Ratelband 2000:34, 45).

26. One of the first board meetings of the WIC, in the fall of 1623 , revealed some reservations regarding the moral legitimacy of the Angolan slave trade. Even so, there is evidence that the Dutch already made use of slaves on the African coast itself, as suggested by early Dutch activities at Cabo Verde and on the island of Principe. See De Jonge 1862:235 and Enthoven 2003.

27. The term "incidental" occurs several times throughout the historiography of the Dutch slave trade, but Emmer developed it most clearly. There is some scattered evidence that several Portuguese slave ships captured by the Dutch in the 1620 s were released with their slaves, either for practical reasons (no market to sell them, other sailing priorities) or perhaps because the captains personally abhorred the practice. Later on, slaves based on Curaçao who served on intra-Caribbean vessels often received fake freedom papers so that, in case of a hostile attack in open waters, they could not be confiscated as "contraband"; I thank Han Jordaan for pointing this interesting fact out to me.

28. Because TSTD assigns nationality of slave voyages based on departure at the African coast, these incidental slaves are all listed under the Portuguese flag, even if they disembarked in the Americas from Dutch ships. 
Qualitatively, however, some of these slaves caused a historic impact far greater than their numbers may suggest. Which slaves, for example, received more attention than the twenty Africans delivered in 1619 by "a Dutch man of warre" to the English settlers at Jamestown, Virginia? ${ }^{29}$ In various other Protestant settlements in the New World (New Netherland, Bermuda, Barbados, Tobago, Guianas) warfare and privateering were often responsible for the arrival of the first Africans. ${ }^{30}$ Almost all originated from West Central Africa (Congo-Loango, Luanda, Benguela), which between the 1580 s and 1640 s possessed a virtual monopoly on slave exports. Some of the names assigned to the first African residents of New Amsterdam - Paulo d'Angola, Anthony Portuguese, Simon Congo, Assento Angola - confirm this Portuguese-Angolan connection (Berlin 1996:265). ${ }^{31}$ As the first and rather isolated Africans among small communities of struggling settlers from northwestern Europe, this "charter generation" of "Atlantic creoles" (Berlin 1996, 1998, Heywood \& Thornton 2007) witnessed the slow crystallization of slavery before its own eyes. At times, they may have experienced a level of freedom and social mobility that was generally absent among future generations of African American slaves.

The conquest of Pernambuco and several other Portuguese captaincies in northeast Brazil during the early 1630s handed the WIC the richest sugar-producing area in the world, and a full-blown slave society at that. The Company officials soon came to the realization that without slaves, sugar cultivation was in danger. After the surrounding rural areas were sufficiently "pacified," the WIC began expanding its commercial interests on the African coast by simply conquering long-established Portuguese trading posts. Earlier attempts to do so had failed miserably (Ratelband 2000, Den Heijer 2006), but victories at Arguin (1633), El Mina (1637), and São Paulo de Luanda and São Tomé (1641) guaranteed an unprecedented Dutch dominance on the African coast. Never would the Dutch have easier access to slaves than during the 1640s (Ratelband 1953, 2000).

29. Most histories of slavery in the U.S. begin with this shipment arriving at Jamestown. Slavery in seventeenth-century colonial Virginia in general has received much more attention than its historical proportions justify. For recent information on these particular slaves, see Sluiter 1997 and Thornton 1998. One question that continues to preoccupy historians of colonial North America is whether these Africans were treated as slaves or not, but that they left the African continent as slaves should be clear.

30. Wim Klooster (1998:105) mentions Angolan slaves at the Dutch forts on the Xingú River in 1623, and hundreds of slaves among the Dutch at Cayenne in 1644; the patroonship of Jan de Moor on the island of Tobago, established in 1628, was arguably the first Dutch plantation colony in the Americas. The English slave trade had also originated from privateering activities, namely by the Elizabethan "sea dog," John Hawkins, in the 1560s. 31. This historic connection between New York and West Central Africa (Congo and Angola) has recently been reawakened through cultural exchanges; the first slaves continue to be studied more than their number warrants. 
The history of Dutch Brazil can be divided into three acts: first, the conquest and consolidation of a sizeable territory for sugar cultivation, followed by a decade of relative peace and prosperity under the enlightened governorship of Johan Maurits van Nassau, and, finally, renewed warfare with the local Portuguese colonists leading to the ultimate surrender of the colony in 1654. During the government of Maurits, thousands of slaves were imported by the WIC, heralding the official involvement by the Dutch in the transatlantic slave trade. At first, these slaves were mainly procured from the Calabar region (Slave Coast, Bight of Benin, and Bight of Biafra) and the region north of the Congo River (Van den Boogaart \& Emmer 1979:360). But, partly fueled by the traditional preferences of the Portuguese-Brazilian sugar planters (moradores) for Angolan slaves, the main port of Luanda was taken in 1641.

The increasing volume of slave imports and sugar exports in the 1640s came to a sudden halt when open hostilities broke out shortly after Maurits had returned to Europe. Everywhere sugar plantations and mills were burned to the ground or halted their production. The effects of war and peace on sugar and slavery in Dutch Brazil are clearly visible in Table 4; the first decade of Dutch participation in the transatlantic slave trade was, as the reader can see, quite impressive. ${ }^{32}$

While the "Brazilian adventure" was, for the shareholders of the WIC at least, a financial disaster, it also taught the Company important lessons about the operation of the transatlantic slave trade and the organization of slave-based sugar production, and that trusting a policy of religious toleration to secure the loyalty of resident Portuguese planters had been naive. For Brazilians today, this era of religious toleration spurred by the charisma of the "humanist prince" of Nassau and the many cultural and architectural achievements stimulated by him is exactly what makes this Dutch episode so unique and admirable. ${ }^{33}$

Even so, the import of thousands of African slaves during Maurits's reign hardly deviated from the slave trading patterns before and after the Dutch period. In the first quarter of the seventeenth century alone, the Portuguese shipped approximately 150,000 bonded Africans to Brazil (Klein 2004:230). ${ }^{34}$

32. While most periodizations are inherently subjective, this one may have its merits. My main concern here is to make visible the sudden rise and fall of the Dutch Brazilian plantation complex which, for example, would be missed when one sticks to the annual average of 721 slaves exported by the Dutch in the period 1600-1645 (Postma 2003a:137).

33. For a recent assessment of the Dutch policy of religious toleration in Brazil, see Israel \& Schwartz 2007.

34. That a significant proportion of the Brazilian sugar produced in the first two decades of the seventeenth century was traded on the Amsterdam exchange, only indicates that the Dutch were already profiting from plantation slavery before they began directly participating in it themselves, see Ebert 2003. 
Table 4 Estimated slave imports and sugar exports in Dutch Brazil, 1630-54

\begin{tabular}{lccl}
\hline Period & Slave imports & Sugar exports** & Political developments \\
\hline $1630-35$ & $280^{*}$ & 154,169 & Conquest and pacification \\
$1636-45$ & 23,500 & $2,433,742$ & Relative peace and prosperity \\
$1646-54$ & 1,700 & 240,848 & Renewed guerrilla warfare \\
\hline
\end{tabular}

Source: Slave imports: TSTD2 comes close to Wättjen $(1913: 421 ; 1921)$, who gave a total of 23,163 slaves imported by the Dutch during the peak decade, especially considering that TSTD2 includes 210 slaves imported by the Dutch to Bahia and 140 slaves to an unspecified destination in Brazil. Wättjen's figures for 1642-1643 are lower than those given by Johan Maurits van Nassau in a report to the States General of the Dutch Republic in 1644: according to that report the slave trade registers revealed that between February 7, 1642 and July 23, 1643, roughly one-and-a-half years, 6,468 slaves had embarked, of whom 1,524, or almost a quarter (!), would perish during the Middle Passage (Gonsalves de Mello 2001:199-200).

* The 280 slaves imported in 1630 were incidental Angolan slaves, taken from a captured Portuguese vessel (and should as such not fall under Dutch slave imports in TSTD2), see Van den Boogaart \& Emmer 1979:358. Sugar exports: Wättjen (1921:316-23) as cited by Den Heijer (2003:88); these export figures start in 1631 and end in 1651, but except for the sugar looted at the conquest of Pernambuco, I do not foresee substantial additions here.

** Sugar was measured in arrobas, one arroba being approximately $14.75 \mathrm{~kg}$ (Den Heijer 2003:88), which would imply that during the peak decade the Dutch exported almost 36 million kg of sugar from Pernambuco to Europe.

In this respect, the Dutch slave trade to Brazil may have generated less of a historic impact than the few incidental slaves delivered to other locations in the New World in the previous decades. The Dutch did introduce more slaves from West Africa to Brazil, primarily from the Slave Coast, thereby perhaps introducing the first Igbo from the Bight of Biafra in Pernambuco as well (Vos, Eltis \& Richardson forthcoming). As a result the diversity of the local African population was somewhat augmented, although this was arguably but a marginal number compared to the great majority of Angolan slaves imported from West Central Africa during the entire seventeenth century.

War undoubtedly had a dramatic but also liberating effect on the lives of slaves in Brazil. New slaves arriving from Angola could no longer be sold or fed by the Company. The Hoge Raad in Recife begged its WIC colleagues in Luanda to stop sending slaves across the Atlantic, and those who had already arrived were now redirected north. In January 1646 the Tamandare sailed with a cargo of slaves from Fernando da Noronha via Barbados to New Amsterdam. The relative ease with which this merchandise was sold appeared as a harbinger of things to come (Ratelband 2000:225, 259). With Dutch Brazil sliding into the chaos of civil war in the mid-1640s, the WIC faced a dilemma: what should be done about the slave trade, especially after its short-lived supremacy on the African coast was eroded when the Portuguese recaptured Luanda and São Tomé (1648) and the English slaving activities were expanding?

Past historians have argued that the Dutch opened new markets for slaves in the English and French Caribbean by introducing slave-based sugar cul- 
tivation closely resembling the Brazilian model. ${ }^{35}$ This interpretation seems to fit the historic timeline quite nicely, just as the fact that during the $1650 \mathrm{~s}$ and 1660s, before the acquisition of Suriname and the rise of the Curaçaoan asiento trade, the Dutch mostly transported slaves to colonies of other Europeans (see Table 3). However, recent empirical research by John R. McCusker and Russell R. Menard (2004) strongly diminishes the Dutch role in the so-called "Barbadian sugar revolution" by pointing at a much greater English involvement than previously thought. ${ }^{36}$ The First Navigation Act (1651) established under Cromwell was mainly intended to suppress Dutch trade to the English colonies and fueled the growing animosity between the two maritime superpowers, eventually leading to three naval wars between 1652 and 1674. Increasingly stifled by the mercantilist policies of England and France, the Dutch looked - ironically perhaps - to the colonies of their former enemy Spain to provide new markets for the slave trade. ${ }^{37}$ Between 1646 and 1657, Dutch traders sold about 3,800 slaves to Santo Domingo, Puerto Rico, and Tierra Firme (Klooster 1998:106), while between 1657 and 1663 fourteen Dutch slave ships arrived at Buenos Aires in the Río de la Plata region alone (Moutoukias 1988:143-47). ${ }^{38}$

It is in this volatile arena that the emergence of Curaçao as a slave trade entrepôt for the Spanish Americas should be situated. No longer useful as a military base now that the war with Spain had ended, and never entirely suited for commercial plantation agriculture, the Company was desperately looking for another niche. For the next half century, Curaçao would take advantage of the asiento trade, receiving "saltwater" slaves from Africa and distributing them to the Spanish Americas according to contracts made in Europe. The asiento contracts were renewed and reconfigured several times during the second half of the seventeenth century, thereby consolidating the Dutch position as a major player in the transatlantic slave trade (Klooster 1997).

35. For example, Curtin 1969:125-26; elsewhere he states that "up to 1663, the slave trade to Barbados was practically a Dutch monopoly" (Curtin 1969:55).

36. The authors are diminishing the Dutch role, while at the same time suggesting its continued importance. It remains hard to establish and measure the more immaterial contributions. After the first Navigation Act, the English colonists were most likely inclined to hide any illicit Dutch trade from the records. At the same time, WIC records at Elmina show an increase in English shipping for slaves in the mid-1640s (Ratelband 1953).

37. The end of the Eighty Years' War (1648) created new possibilities for Dutch traders in slaves and other colonial goods. Because Spain was still in conflict with Portugal, until 1640 the primary slave carrier for the Spanish Americas, its colonists were searching for other ways to procure slaves.

38. Río de la Plata was notorious as a smuggling port at the periphery of the Spanish Americas. Klooster (1998:53) notes, based on Moutoukias, that it was the most frequently visited place in Spanish America by the Dutch between 1655 and 1665, with 63 voyages in total, and that there was even a small resident population of Dutch and Flemish in Buenos Aires. 
Altogether almost a 100,000 slaves, or roughly 20 percent of the entire Dutch slave trade, accordingly found their way to the Spanish Americas between 1658 and 1729, with a sizeable number from the Slave Coast, thus further diversifying the ethnic make-up of the Spanish colonies (Klooster 1998:107). Except for their short "layover" at Curaçao and their impact on the island economy, most of these Africans quickly disappeared from the Dutch colonial realm. And while this transit trade enhanced the historic reputation of the Dutch as slave traders, the slaves themselves ended up in Spanish, not Dutch colonies. ${ }^{39}$

With Curaçao evolving into "Amsterdam's Caribbean counterpart" (Klooster 1998:59), other Dutch colonies in the Americas received slaves only sparingly during the 1650s and 1660s. Governor Peter Stuyvesant of New Netherland repeatedly requested slaves from Curaçao, but only a few actually arrived (Emmer 1972a:115). Sound business acumen, not national solidarity, ensured that most surplus or "refuse" slaves were sold closer to home, and usually at much better prices. New Netherland simply could not compete with the Caribbean plantation colonies in their demand for slave labor. Of the two large slave cargoes arriving in New Amsterdam, most of the slaves of Het Witte Paert (1654) were quickly resold to tobacco planters in the Chesapeake, and the 290 slaves disembarking from the Gideon were just in time (eight days left!) to witness the peaceful surrender of New Amsterdam to the English. ${ }^{40}$ New Netherland was by all accounts never more than a peripheral destination in the slave trade, even if the small stream of slaves arriving would lay the foundation of a vibrant African American community. ${ }^{41}$

The Peace of Breda (1667), settling the Second Anglo-Dutch War and swapping New Netherland (New York) for Suriname, would greatly impact the future of the Dutch transatlantic slave trade. For the next century and a half, the Dutch colonial possessions in the Americas would remain largely unchanged. One could even say that the failed colonization of New Holland

39. The English were also important in the slave trade to the Spanish Americas, with Jamaica functioning as a competing slave entrepôt to Curaçao. However, Jamaica differed from Curaçao, as the island was also home to a substantial plantation sector, thereby giving it a more diversified economic character than the Dutch colony.

40. In 1655 the governor and council of New Netherland supported a 10 percent duty on the sale of each slave exported from the colony, because almost all slaves brought by Het Witte Paert had left the colony again. This was the moment when the Chesapeake tobacco plantations began replacing British indentured servants with African slaves. For the connections between Chesapeake planters, some of whom had Dutch backgrounds, and New Amsterdam-based merchants, see Hatfield 2003.

41. That around $1664 \mathrm{New}$ Amsterdam possessed "the largest urban slave population on mainland North America" (Berlin 1996:269) says more about the slow emergence of racial slavery in the Chesapeake and the stunted growth of its cities than any acute demand for slaves in the Dutch trading post. 
(Dutch Brazil) and New Netherland (Dutch New York) made the WIC domain leaner and meaner, and heavily concentrated on the lower Caribbean. This suited the financial and structural reorganization of the Company in the early 1670 s very well. With Curaçao now in its golden age as a slave trade entrepôt to the Spanish Americas and with Suriname emerging as the quintessential Dutch plantation colony, the future opportunities for the slave trade looked promising.

The original documentation of the Second WIC (1674-1792) has fortunately been much better preserved than that of its predecessor. From the viewpoint of the transatlantic slave trade, this entire period is best divided into two parts: the era of the WIC monopoly and, from the early 1730 s on, the era of the private slave trade. Henk den Heijer's (1997) research on the slave trade of the Second WIC gives a good impression of the origin, volume, and destination of these voyages (see Tables 5 and 6).

Table 5 Slave exports Africa under the Second WIC, 1674-1740

\begin{tabular}{lccccc}
\hline Period & El Mina & Slave Coast & Angola & Various & Total \\
\hline $1674-1689$ & 10,553 & 16,543 & 22,207 & 14,861 & 64,164 \\
$1690-1704$ & 3,745 & 22.035 & 17,017 & & 42,797 \\
$1705-1719$ & 4,712 & 18,433 & 7,640 & 1,248 & 32,033 \\
$1720-1740^{*}$ & 24,028 & 18,099 & 9,356 & & 51,483 \\
$1674-1740$ & 43,038 & 75,110 & 56,220 & 16,109 & 190,477 \\
Percentage & 22.6 & 39.4 & 29.5 & 8.5 & 100 \\
\hline
\end{tabular}

Source: Adapted from Den Heijer (1997:151).

* This period is six years longer than the others.

Table 6 Slave imports Americas under the Second WIC, 1674-1740

\begin{tabular}{lccccrc}
\hline Period & Curaçao & Suriname & St. Eustatius & Essequibo Berbice & Various & Total \\
\hline $1674-1689$ & 31,642 & 12,490 & 668 & 754 & 7,758 & 53,312 \\
$1690-1704$ & 17,849 & 10,180 & & 1,659 & 5,985 & 35,673 \\
$1705-1719$ & 10,726 & 12,549 & 446 & 1,536 & 480 & 25,737 \\
$1720-1740^{*}$ & 2,270 & 25,565 & 9,747 & 2,503 & 1,916 & 42,001 \\
$1674-1740$ & 62,487 & 60,784 & 10,861 & 6,452 & 16,139 & 156,723 \\
Percentage & 39.9 & 38.8 & 6.9 & 4.1 & 10.3 & 100 \\
\hline
\end{tabular}

Source: Adapted from Den Heijer (1997:152).

* This period is six years longer than the others. 
According to Table 5 the forced migration of Angolan slaves gradually declined during this period, while the Slave Coast remained a relatively stable supplier throughout (primarily from the Bight of Benin, as the Bight of Biafra was increasingly dominated by English slavers, see Table 2) and Dutch Elmina underwent a dramatic transformation from gold to slave exporter. As this transformation took place after Curaçao had lost its function as a slave entrepôt, it is plausible that most slaves from the Gold Coast found their way to Suriname through Elmina, confirming the oft-celebrated historic connections between these two colonial possessions of the Dutch.

Curaçao and Suriname were the primary beneficiaries of the Dutch slave trade in this period, receiving almost equal numbers, with the crucial difference being that most slaves to Curaçao were transferred to Spanish colonies, while Suriname functioned as an end destination (see Table 6). Between 1676 and 1716 over 42,000 African slaves arriving at Curaçao were distributed among Spanish traders (Postma 1990:45, 48). When, after the War of Spanish Succession (1702-1713), the asiento contracts fell squarely into English hands, the slave trade to Curaçao rapidly declined. ${ }^{42}$ Not only did this have immediate effects on the island's economy and the activities of the local Company slaves (Jordaan 1997, 1999, 2003), but it would result in a rapid creolization of its African American population and the sustained growth of a free black community (Klooster 1994, 1999). ${ }^{43}$ It appears that St. Eustatius took up some of the slack of the transit trade in the 1720s, but their trade was more focused on the French Caribbean and, later in the century, on North America as well. ${ }^{44}$

During the 1730 s the WIC relinquished its monopoly on the transatlantic slave trade, leading to the emergence of a large private slave trade and the end of its illegal forerunners, the interlopers. Companies such as the Middelburgsche Commercie Compagnie (MCC) and the Rotterdambased firm of Rochussen were now mainly responsible for delivering slaves to Suriname and the smaller Dutch plantation colonies on the Wild Coast (Berbice, Essequibo, and Demerara). ${ }^{45}$ As a consequence, the historic con-

42. According to Jordaan (2003:220) "independent shippers landed nearly 10,000 slaves at Curaçao between 1730 and 1795, illustrating the island's diminished role in the traffic."

43. For the remainder of the eighteenth century Curaçao nevertheless continued its other - mostly illegal - trade relations with the Spanish Americas, particularly with the eastern parts of Venezuela; see Klooster 1998.

44. During the 1770s, at the time of the American War of Independence, St. Eustatius earned the nickname "the Golden Rock" owing to its free trade and smuggling activities. In the period 1775-1779 the island received around 4,000 slaves from Africa - most were undoubtedly intended for further trading.

45. The Dutch presence on the Wild Coast dated all the way back to the end of the sixteenth century, but had frequently suffered from hostilities with Native Americans, as well as Spanish, English, and French colonizers. Interestingly, Berbice and Essequibo, with an older Dutch history than Suriname, were ultimately incorporated into British Guiana, 
nections between Zeeland and the Wild Coast were rekindled, with almost 80 percent of the Dutch private slave trade organized by companies from that maritime province.

The extent to which this trade expanded dramatically in the mid-eighteenth century, before decreasing just as rapidly during the latter decades, becomes clear from Table 7. This decline can be contributed to two factors: first, the state of the Suriname plantation society itself, which suffered from a financial crisis and limited profitability, ${ }^{46}$ partly related to the continuous resistance of the Maroon communities; second, the general decline of the Dutch Republic, no longer a major player in Europe, with English supremacy in the Fourth Anglo-Dutch War (1780-1784) confirming the loss of their maritime prowess.

Further breaking down the Dutch slave trade to the Guianas, an estimated 160,200 slaves disembarked at Suriname during the eighteenth century according to Postma (2003b:306), whereas a much smaller figure of 20,300 slaves went to Essequibo and Demerara via Dutch ships (Van der Oest 2003:335). This would leave - barring dramatic differences between these various estimates - about 34,000 slaves brought to Berbice on Dutch vessels during the eighteenth century. Essequibo and particularly Demerara, which opened for settlement in the 1740s, were promising and quickly developing plantation colonies, with most of their slaves arriving in the later decades of the eighteenth century.

The inability of the Dutch to keep pace with these economic developments was quickly answered by increased British and U.S. slave trading activities: Postma (2003b:306) mentions a total of 7,011 slaves arriving in Suriname on U.S. ships during the 1780 s and 1790 s, with the British focusing predominantly on Essequibo and Demerara, especially after occupying these colonies in $1795 .{ }^{47}$ The colonies were shortly returned to the Dutch during the era of the Batavian Republic (1795-1805), much to the chagrin of even the Dutch planters. A total of six Dutch slave voyages in 1802-1803 delivered an estimated 1,287 slaves to Suriname (Postma 2003b:306). The TSTD2 projects that during this Dutch interregnum British slavers still brought 18,200 of the foreign slave imports to the "Dutch" Guianas, mostly to Essequibo and Demerara, and another 71,500 slaves in the English period before the prohibition of the international slave trade.

while Suriname, which began as an English colony, remained Dutch. Demerara was only opened for colonization in the mid-eighteenth century and attracted mainly British planters from Barbados.

46. For a critique of this colonial crisis thesis, see Van Stipriaan 1995.

47. Logically, as English colonists already owned a third of the 130 young plantations in Demerara during the 1760s and worked by slave labor "between 1789 and 1802, exports of sugar rose by 433 percent, coffee by 233 percent, and cotton by 862 percent ... Fabulous fortunes were made in a short period" (Viotti da Costa 1994:43). 
Table 7 Estimated slave imports into Dutch colonies in the eighteenth and the nineteenth century*

\begin{tabular}{|c|c|c|c|c|c|}
\hline \multirow[t]{2}{*}{ Period } & \multicolumn{2}{|c|}{ Dutch Caribbean** } & \multicolumn{2}{|c|}{ Dutch Guianas } & \\
\hline & $\begin{array}{c}\text { Dutch } \\
\text { voyages }\end{array}$ & $\begin{array}{c}\text { Other } \\
\text { voyages }\end{array}$ & $\begin{array}{c}\text { Dutch } \\
\text { voyages }\end{array}$ & $\begin{array}{c}\text { Other } \\
\text { voyages }\end{array}$ & \\
\hline $1701-1725$ & 29,200 & 0 & 24,200 & 0 & \\
\hline $1726-1750$ & 10,800 & 2,100 & 60,000 & 0 & \\
\hline $1751-1775$ & 16,100 & 100 & 100,700 & 1,200 & \\
\hline $1776-1795$ & 4,100 & 3,600 & 29,500 & 5,500 & British Guianas*** \\
\hline $1795-1800$ & 0 & 0 & 0 & 7,900 & 30,600 \\
\hline 18th century: & 68,300 & 5,900 & 214,500 & 14,700 & \\
\hline $1801-1808$ & 0 & 0 & 1,200 & 19,800 & 41,700 \\
\hline \multicolumn{6}{|c|}{ Prohibition of the international slave trade } \\
\hline $1820-1825$ & 0 & 0 & 600 & 3,700 & 0 \\
\hline
\end{tabular}

Source: TSTD2.

* These estimates only pertain to the data in TSTD2; after the transatlantic slave trade became illegal, slave imports into the Guianas came primarily from elsewhere in the Caribbean; this will be discussed in the section under abolition.

** The Caribbean is used here in the narrow sense, only consisting of the Dutch Caribbean islands, whereas the Dutch settlements on the South American mainland are listed under the Dutch Guianas.

*** The British Guianas are the same areas as the Dutch Guianas, but during the English occupation years.

Based on the provenance zones of the Dutch private slave trade in the eighteenth century (see Table 2) it becomes clear that besides a continuous stream of slaves from West Central Africa, the Wild Coast settlements were mainly supplied by slaves from the Gold Coast and, in an entirely new development that still demands further research, from the Windward Coast. This may have been a reaction to the Dutch being driven away from the Slave Coast by the British, but other factors relating to the operation of the private slave trade could also have influenced this change. Of the approximately 100,000 Africans imported into the Dutch Guianas in the third quarter of the eighteenth century, West Central Africa and the Windward Coast supplied around 40,000 each, with the Gold Coast adding the remaining 20,000. These migration streams influenced the diversity of the slave population of Suriname substantially, and gave the colony a continued African impulse largely absent from the rapidly creolizing African population of Curaçao.

Van Stipriaan's latest estimates on the post-1808 slave trade suggest, based on a multitude of sources, that approximately 33,000 slaves entered Suriname between 1808 and 1830, of which 8,000 during the years of the English occupation until 1816, and 25,000 thereafter. ${ }^{48}$ But most of these

48. This is based on personal notes shared by Van Stipriaan, who will soon publish his research findings in the journal Aquandah. In his earlier work Van Stipriaan (1993:102-104, 
slaves came directly from other Caribbean colonies (mainly the French West Indies, but also English and Danish colonies), and entered Suriname legally. And because they did not constitute new slaves from Africa, they should not be counted toward the transatlantic slave trade. Even so, their arrival from various locations in the Atlantic World, driven by the ingenuity of regional slave traders, led to an even greater ethnic and cultural diversity of the African American population. ${ }^{49}$ The slave trade was a defining experience in the history of Suriname.

\section{By Comparison: The Dutch Slave Trade IN THE INDIAN OCEAN WORLD}

Compared with our remarkably detailed knowledge about the transatlantic slave trade, our understanding of the slave trade in the Indian Ocean World is astonishingly poor. If not for the ubiquity of slaves in the historical documents, it would be easy to forget slave trading had taken place at all there. Until recently, it certainly has not preoccupied historians to any great extent. One reason for this is that slave trading constituted only a minor part of the commercial activities of the Company itself. Historian Els Jacobs has estimated its net worth at only 0.5 percent of the entire VOC trade in the eighteenth century (Vink 2003:235). It was thus insignificant in comparison with the high profits from the pepper, coffee, and tea trades. The Company was apparently "content to leave this trade to 'private enterprise,' albeit under certain restrictions" and free burghers in Batavia - Europeans, mestizos, and in the eighteenth century, the Chinese - became the "the biggest slave traders in Asia" (Van der Kraan 1983:330). ${ }^{50}$ But the documentation regarding this private slave trade, including that of already established indigenous merchants, is more scattered, incomplete, and anecdotal than we would like. ${ }^{51}$

314) had already come - largely based on population data - to an estimate of around 12,000 slaves entering the colony between 1817 and 1826 .

49. With slaves coming from the Caribbean still receiving legal status, while the slave trade with Africa was already prohibited, it is not inconceivable that slave traders legitimized their cargo by assigning the slaves a New World identity. The decreased supply of new slaves drove up prices and this was again an extra incentive for slave traders to "go the extra mile."

50. Van der Kraan (1983:339 n.10) points out that since the 1720s the VOC levied an extraordinarily high duty of ten rijksdaalders per slave sold on the Batavian market. Sutherland (1983:270) tentatively suggests that the private trade could have been at least six times the size of the Company trade in the mid-eighteenth century.

51. For the sake of historical documentation, it did not of course help that, according to Sutherland (1983:283 n.2) "at various times limits were placed on private trade" and "what was prohibited was the trade in people who were not legitimately enslaved ... In theory, since 1699 , all slaves had to be properly documented and sales had to be regis- 
This makes it extremely difficult to make even guesstimates about the nature, volume, and directions of these forced migrations.

First of all, the national involvement in the Indian Ocean slave trade is infinitely more complicated and diverse, which makes the temporal boundaries much harder to define. The transatlantic slave trade has, as we have seen, a clearly demarcated history from beginning to end, spanning almost four centuries. Because it was an entirely European affair, if we accept that the participation of independent American nations such as the United States and Brazil can be attributed to the descendants of European settlers, it is relatively easy to oversee. The vast majority of Atlantic Ocean slave voyages were organized in, departed from, and returned to European ports, even if quite a few were illicit. This metropolitan origination was entirely absent from slave voyages in the Indian Ocean World, and as a consequence they remained more hidden from public view and administrative record-keeping in Europe.

Furthermore, since an extensive regional slave trade already existed before the arrival of the Europeans in Asia, and sometimes persisted after Europeans had relinquished the practice, a clear beginning and end to this slave trade are missing. Europeans never monopolized this economic activity in Asia. An estimate of the total volume of the slave trade in the Indian Ocean World therefore seems well-nigh impossible. After all, we cannot simply rely on the European and colonial archives alone, but need some understanding of the absolute and relative shares of Chinese, Indian, Arabic, African, and local traders, and to what extent they operated independently from, or in cooperation with the Europeans.

With local African and Asian forms of slavery rooted in premodern traditions, Europeans may have influenced or even transformed these systems through increased demand, but they could never fully command its perimeters. Slavery in the New World consisted entirely, after the gradual exclusion of Native American slaves, of sub-Saharan Africans. Such a clear racial identification of, and connotation with, slavery never materialized in the Indian Ocean World, even though in the ethnocentric mind-set of Europeans, both Africans and Asians alike could be defined as "black." 52 True, lightness of skin had its positive merits in the Indian Ocean World as well, but theoretically a wide pool of racial, ethnic, national, and religious groups were eligible for enslavement, at times even including Europeans themselves. Comparable

tered, but given the high profits, this stipulation was evaded by many traders, and a high proportion of slave transactions involving Europeans were in fact illegal, while the indigenous trade was beyond the Company's reach."

52. Of course, if it had been highly profitable to transport Asian slaves to the Caribbean sugar plantations (which, before the nineteenth century, it was not), then slavery in the Americas could have lost some of its racial exclusivity. Still, the lack of a large free population with a similar ethnic background as the slaves would have ensured that the unique power dynamics of colonial slavery in the Americas remained intact. 
to the often irrational preferences that European colonists in the New World showed for specific Africans, an abundance of theories existed regarding the attributes of particular slaves in the Indian Ocean World. Here, as in the West, African slaves were often considered ideal for hard, backbreaking labor conditions. ${ }^{53}$ Additionally, Hindu slaves from Malabar were praised for their technical skills, female slaves from Bali for their domestic labor and as potential future marriage partners, while Buginese Muslims from South Sulawesi were frequently shunned for their supposed rebelliousness, to give but a few of the existing stereotypes.

Yet, despite such ethnic typecasting, slave identity in the Indian Ocean World was never encapsulated in one clear racial classification. This situation was further enhanced by the presence of much larger free populations who shared ethnic and religious backgrounds with the slaves. A simple demographic breakdown of a colonial settlement can, therefore, tell us little about who had in fact arrived as a forced migrant and who came out of free will. Since dependency was almost equally distributed among a great mixture of peoples, it was then, and still is now, extremely difficult to establish one single, unambiguous slave identity.

This multi-ethnic character of Indian Ocean slavery creates even more confusion if we attempt to chart the geographic directions of the regional slave trade. There may have been "many middle passages," as a recent comparative treatment of forced migrations in the modern world puts it (Christopher et al. 2007), but none was as clearly a physical and cultural transition as the one-way journey of African slaves to the Americas. Unless we somehow include the more than half million southeast African and Malagasy slaves shipped to the Americas, forced migration patterns in the Indian Ocean World appear to crisscross one another, demonstrating a multidirectionality unseen in the Atlantic system. ${ }^{54}$ Slaves could embark virtually anywhere in the region and be shipped to a variety of destinations and destinies. Monsoon winds further dictated seasonal shipping patterns and prevented the transoceanic slave trade taking on any year-long regularity, making estimates even more complicated.

53. In his Itinerario (1596) Van Linschoten already commented that the slaves from Mozambique (east Africa) were in high demand all across the East, "because they are the strongest of the entire Orient, and do the dirtiest and harshest work, and only for that they are used" (Terpstra 1955:25). This perception may have been intensified by the use of African slaves by Portuguese colonists during the sixteenth century.

54. TSTD2 estimates that a total of 542,700 slaves were exported from southeast Africa and the Indian Ocean islands, a similar number to the entire Dutch transatlantic slave trade. Of those slaves, an estimated 436,500 arrived in the New World, suggesting a mortality rate of almost twenty percent (19.6). The greater length of the Middle Passage should largely account for this stunningly high mortality rate, although most of these slaves were transported during the nineteenth century, when shipping technology had clearly improved. 
The widespread use of slaves as domestic servants by their European owners made it more likely that a single slave was subjected to several long-distance migrations in his life, often in opposite directions. Obviously, this significantly increases the risk of double- or even triple-counting the same slave, a key obstacle to assessing the total volume of the trade. Once again we are struck by what a uniquely one-directional voyage the transatlantic slave trade really was. For that matter, the Indian Ocean slave trade bears more resemblance to the intra-American slave trade, as colonists and their slave property moved from one colony to the next, for example, from Barbados to South Carolina or from Saint Domingue to Louisiana. Yet such slave migrations have wisely been left outside the definition of the transatlantic slave trade.

Because the informal VOC empire spanned across and beyond the Indian Ocean World (ranging all the way from Cape Town, South Africa, to Dejima, Japan), the multidirectionality of the slave trade was only further stimulated. Batavia was the uncontested central cog in this supraregional trade system, but key VOC possessions such as the Banda Islands, Ceylon (Sri Lanka), and the Cape Colony all demonstrated a relatively independent pull for slaves, and adequate oversight on this traffic was usually absent. VOC officials and private burghers traveling between these Dutch trading posts often brought their personal and trade slaves along, thereby adding to the administrative confusion and cultural diffusion. Non-Dutch traders, Europeans as well as non-Europeans, transporting slaves on water and over land, further complicate the issue.

Faced with some of the challenges and difficulties addressed above, Markus Vink (2003) has attempted to assess the volume of the Dutch Indian Ocean slave trade by using a method not uncommon to scholars of the transatlantic slave trade. As the records of slave departures and arrivals are simply too patchy, and to circumvent the problem of double-counting, he decided to approach the problem from the demand rather than the supply side: how many slaves had to be imported each year into the VOC possessions to keep their slave populations at a relatively steady level? Based on slave population figures from original VOC documentation and a variety of other primary and secondary sources, Vink calculates that around the year 1688 between 4,476 and 7,716 slaves had to be exported annually to allow - after assessing a 20 percent morality rate - for the necessary slave imports. Based on these estimates, Vink (2003:168) draws the conclusion that "the volume of the total Dutch Indian Ocean slave trade was therefore $15-30 \%$ of the Atlantic slave trade ... and one-and-a-half to three times the size of ... the Dutch West India Company slave trade."

Anyone familiar with the Dutch Atlantic slave trade will likely be stunned by this bold assertion, even after realizing that the statement is merely valid for the late 1680s. Upon checking with the most recent estimates for the transatlantic slave trade, it appears that Vink's comparison holds up for the 
entire volume of that trade, yet that he substantially underestimated the Dutch: 1687 and 1688 were actually peak years for the Dutch slave trade, as they were then in command of the asiento trade, with an estimated 6,900 and 5,900 slaves exported, respectively (TSTD2). But if we consider, in line with renowned scholars (Postma 2003a), that the Dutch transatlantic slave trade actually reached its highest point during this period, Vink's estimates for the Eastern trade continue to impress us. Putting both slave trades together would suddenly make the Dutch a major, if not the dominant, player in the colonial slave trade of the late seventeenth century. ${ }^{55}$ This was surely the "Golden Age" of the Dutch slave trade.

A 20 percent mortality rate may perhaps strike the reader as high, especially considering that the maritime routes were generally shorter than in the Atlantic Ocean and that many slaves could be procured from the nearby hinterlands. ${ }^{56}$ But assuming for the moment that Vink's calculations are reasonably accurate - and there is no apparent reason to believe otherwise - the pressing question remaining is how the estimate for the year 1688 relates to the entire span of the Dutch Indian Ocean slave trade. If we, against better judgment, multiply it by, say, 180 (years), we arrive at roughly 675,000 to $1,150,000$ slaves transported to the various possessions of the VOC.

Vink (2003:167) humbly underlines that he is only providing a "tentative census" and that much more archival research is needed to begin sketching a historical development over time. Using his techniques this would be an extremely taxing exercise, as one would need access to yearly slave population counts for each individual settlement, their respective birth, mortality, and manumission rates, mortality rates for the various slave trading routes, and many other important contingencies. It is not difficult to imagine how such a method could lead to dramatic misrepresentations. If, for example, we took a snapshot of Dutch Brazil in the early 1640s and extrapolated this over the entire twenty-five-year life span of that colony, its slave imports could easily be exaggerated up to five times their actual size. Supply of, and demand for, slaves are always highly volatile forces in history.

It is, nevertheless, quite reasonable to believe that the slave trade in the Indian Ocean World operated more independently from market fluctuations than its Atlantic variant. Slaves in the VOC domain were seldom intensively used in the production of commodities for the European market. Even in the

55. Without even taking into account that, judging from Paesie 2008, the volume of the illicit Dutch slave trade to the Americas in this period might have to be upgraded as well. 56. Such a percentage certainly seems warranted when considering the forced migration of Malagasy slaves to the Sillida gold mines at West Sumatra during the 1670s and 1680s, which was "every bit as horrific as the "middle passage' across the Atlantic," with several hundred slaves packed into extremely crammed conditions (Barendse 1995:141-45). In their organization, distance traveled, duration, and shipboard mortality, these specific VOC slave voyages easily rivaled the triangular transatlantic slave trade. 
case of nutmeg cultivation on the Banda Islands, where slave labor was utilized in a way resembling Caribbean plantations, the monopoly established by the Dutch prevented a market-driven expansion of the slave population. ${ }^{57}$ In the great majority of VOC possessions, however, most slaves functioned as domestic servants to free European and Asian burghers. Evidently, the demographic ebb and flow of the colonists and the growth and decline of their respective slave holdings were closely related to the health of the colonial economy. Nonetheless, an estimation based on the perspective of supply may have its merits here. The general size of the free populations of various VOC possessions certainly appears to reveal a more direct correlation to their respective slave holdings than in the Western hemisphere. Lacking sufficient data to assess the regional trade and transoceanic movement of slaves, the approach by Vink may very well be the only possible way to quantify the volume of the Dutch slave trade in the Indian Ocean World.

Based on the scanty historical records, we can establish some rough estimates for the major slave trade patterns in the Indian Ocean World. During the seventeenth century, tens of thousands of slaves were procured by the VOC from the Indian subcontinent, first primarily from the Coromandel coast and the Bengal-Arakan region, later also from the Malabar coast and Ceylon. Most of these slaves were destined for Batavia and other locations in the Indonesian archipelago, but later in the century the Cape Colony and Ceylon became important markets as well. Although the trade in Indian slaves declined noticeably during the eighteenth century, it would not be far-fetched to suggest that approximately 100,000 slaves, and possibly more, were taken from this region by the Dutch. The number of slaves drawn from the Indonesian archipelago during the Company era was even higher, with the islands of Bali and Sulawesi each supplying at least more than 100,000 slaves. ${ }^{58} \mathrm{~A}$ third region in the Indian Ocean World from which tens of thousands of slaves were exported to the VOC territories was Southeast Africa (Mozambique) and Madagascar. Malagasy slaves were often faced with uncharacteristically harsh labor conditions, such as sugar cultivation on Mauritius or the gold mines of West Sumatra. If we add all these admittedly ballpark figures up, it may be warranted to state that several hundred thousand slaves were exported to the various colonial settlements of the VOC during the seventeenth and eighteenth centuries, possibly approximating the half million mark of the Dutch transatlantic slave trade.

57. Through its worldwide monopoly on both the clove and nutmeg production, the VOC essentially controlled the market forces and could therefore afford to slow down production (and keep prices artificially high).

58. An older estimate by Sutherland (1983:270) suggesting that during the eighteenth century around 3,000 slaves annually were procured through the port of Makassar alone seems a bit exaggerated. See, for more recent figures based on historical documentation, Knaap \& Sutherland 2004. 
Needless to say, more rigorous archival research is required to get us closer to any responsible estimates of this slave trade, and fortunately there are signs that area specialists are picking up on this theme. It will be a momentous and nearly impossible task to integrate their future findings into something resembling the "Trans-Atlantic Slave Trade Database," considering the many pitfalls involved in the multidirectional Indian Ocean slave trade. Even if we accept that around 63,000 slaves were disembarked at Cape Town during the VOC period, how many of them had been previously traded in the South Asian or Southeast Asian region, either by Dutch or other merchants? Perhaps we should entirely stop trying to measure this unique slave trade in transatlantic terms, and assess it solely on its own patterns. But regardless of the exact numbers, the available evidence certainly warrants a new look at the overall role of the Dutch in the colonial slave trade.

The Dutch transatlantic slave trade can be relatively simply divided between the period of the WIC monopoly and the era of the private slave trade that followed it. The most significant gaps in our knowledge concern the illicit private slave trade (interlopers) during the era of the Company trade and the recent study by Ruud Paesie (2008) has shed light on this topic in an important way. In the Indian Ocean World, the Company slave trade was arguably more important during the seventeenth century as well. Since its trading empire was still expanding, each territorial conquest was followed by the building or strengthening of fortifications and warehouses, backbreaking work that was preferably done with slaves and convicts rather than by Company personnel. The VOC organized several long-distance slave voyages (Coromandel, Bengal-Arakan, Madagascar) but most slaves were transported in smaller shipments, often as additional freight stowed away with the primary commodities. Future research may perhaps reveal whether slaves shipped as part of such mixed cargoes suffered higher mortality rates, or exactly the opposite. The private slave trade in the Dutch Indian Ocean World was more hidden and, apart from the "personal trade slaves" of Company officials and free burghers traveling on VOC ships, more limited to regional networks. A sizeable share of this trade remained in the hands of Asian merchants (Southeast Asia) or was carried on by ships sailing under different European flags (southern Africa). If we apply the same strict national compartmentalization that has been customary in the transatlantic slave trade, a substantial downsizing of the Dutch Indian Ocean slave trade is likely in order.

In recent quantitative assessments of the transatlantic slave trade, the Dutch are relegated to the status of a minor or second-rate carrier (Eltis 2001). It is difficult to argue with the mass of compiled data spanning more than three centuries. But if we narrow the time-frame to the period of the Golden Age, Dutch participation in the transatlantic slave trade grows significantly in importance. Furthermore, if we compare this with the Dutch stake in American slavery, the oft-repeated idea that the Dutch were more successful at trading 
than at colonizing is confirmed once again. In the Atlantic World the Dutch shipped more slaves to colonies of other nations than vice versa and were thus, in sheer numerical and historical impact, of greater importance on the supply side (Africa) than on the demand side (Americas) of the slave trade. This contrast is even further enhanced when we consider that substantial parts of the European population in Dutch colonies, and particularly the planters, were of a non-Dutch background, while on the other hand Dutch investors and skippers often attempted to evade the WIC monopoly by trading slaves under different Protestant flags or illicitly (Ratelband 1953, Paesie 2008). ${ }^{59}$ Even the Company itself was not opposed to allowing its former Portuguese-Brazilian enemies to take slaves along the Gold Coast, as long as they paid a generous duty of 10 percent per slave (Schwartz \& Postma 2003). It can safely be said that no European colonial power demonstrated a greater discrepancy between sending their own citizens abroad and transporting others overseas, either through force or on a more voluntary basis.

How great the destructive impact of these forced migrations was on the various provenance zones in Africa has been the object of an extensive and often heated debate. For the Indian Ocean World, it seems that the densely populated South Asian societies, especially when considering their massive indentured labor migrations that came after the abolition of slavery, were relatively unaffected by the small drainage of manpower. For the major slaveexporting regions in Southeast Asia (Sulawesi, Bali) however, as well as for the island of Madagascar, the effects of the export slave trade must have been more dramatic, both in terms of demographic loss and in stimulating internal warfare, enslavement, and general disorganization. It is moreover quite conceivable that some of the smaller island societies in the eastern parts of the Indonesian archipelago were in fact destroyed beyond repair by slave raiding expeditions instigated directly or indirectly by the Dutch.

\section{The Two VARIAnts of Dutch COLONIAL Slavery}

Ever since the classic study by Frank Tannenbaum (1947), historians have been comparing the various manifestations of New World slavery in an

59. Although I realize that, on the other hand, the mercantile connections of Sephardic Jews played an important role in the development of the Dutch slave trade and, on the other hand, that there are sporadic cases of Dutch planters settling in foreign colonies. For example, Klooster (1998:41-42) mentions a significant population of Dutch planters on Danish St. Thomas (145 out of a white adult population of 383), many coming from Curaçao and St. Eustatius. By 1765 they were still the largest single group on the island, twice as numerous as the Danes themselves, and there was also a Dutch presence on St. John after that island became a Danish colony in 1717. 
attempt to explain the roots of their differences. To some, the key factor was the cultural background of the European colonizer: Iberian slavery was supposedly relatively mild, while English and Dutch slavery was harsh and more brutally exploitative. ${ }^{60}$ Others have objected to these arguments by attributing more weight to the environmental and demographic conditions in the colonies themselves. Since we are here primarily concerned with a comparison of Dutch colonial slavery, we can, in the footsteps of Harry Hoetink's study of race relations (1967), safely eliminate the metropolitan cultural factor. At the same time, our wide global perspective enables us to focus even more closely on the importance of various local conditions in the historic development of colonial slavery. By looking at the demographic size of the slave populations in the Dutch colonial sphere and the specific labor conditions the slaves faced, we can offer some tentative suggestions on how these factors impacted the sociocultural position of the slaves and their historic legacy.

The absolute and relative size of slave populations can be helpful indicators to determine to what extent a particular society was dominated by slavery. Table 8 is an admittedly modest attempt to gather some relevant demographic data for the Dutch colonies in the WIC domain. It irrefutably proves their heavy dependency on slaves.

We must keep in mind that most of these population figures pertain to the Dutch-controlled areas only, and give little indication of the Native American populations surrounding the Dutch colonies. Even so, most of these native populations were not only relatively sparse, especially after coming into contact with European colonists, but their societies were relatively "underdeveloped" and defenseless against European might. Direct territorial colonization was therefore not merely a possibility, but almost obligatory if Europeans were hoping to make long-term profits.

To provide for the much-needed labor, first indentured servants from Europe, then African slaves were imported in droves. ${ }^{61}$ Generally speaking, the population structure of most American colonies became characterized by "black majorities" and, despite occasional hostilities with surrounding

60. See Foner \& Genovese 1969 for an overview of the classic positions on this debate. The cultural arguments by Tannenbaum and Elkins have recently been given new life by scholars like Blackburn 1997 and Eltis 2000 who both argue that certain "progressive" developments in the metropolis (growth of capitalism, freedom, possessive individualism) can be indirectly related to the harsh treatment of slaves by the English and Dutch. Eltis 1999 sees it as a most tragic irony that the rights to liberty and personal freedom these early-modern Europeans enjoyed at home also allowed them to act in a relatively unfettered and unchecked way toward outsiders beyond the European continent.

61. Early Spanish colonization of mainland America, which focused on more densely populated - though ultimately powerless - Aztec and Inca empires, relied substantially on coerced native labor. But the unique development of African slavery there only confirms the essential role of native populations in this process. 
Table 8 Assorted slave and free populations in the primary WIC possessions

\begin{tabular}{|c|c|c|c|c|}
\hline Colony & Year & Slaves & Europeans & Non-Europeans \\
\hline Gold Coast ${ }^{*}$ & 1773 & c.700 (68.2\%) & $180(17.0 \%)$ & $146(13.7 \%)$ \\
\hline - Fort Elmina & 1645 & $192(60.4 \%)$ & $126(39.6 \%)$ & \\
\hline Dutch Brazil & 1640 & c. $30,000(33.5 \%)$ & c. $43,500(48.6 \%)$ & c. $16,000(17.8 \%)$ \\
\hline Suriname & $\begin{array}{l}1738 \\
1791\end{array}$ & $\begin{array}{r}\text { c. } 24,047(89.8 \%) \\
48,155(91.2 \%)\end{array}$ & $\begin{array}{ll}2,133 & (8.0 \%) \\
2,900 & (5.5 \%)\end{array}$ & $\begin{array}{rr}598 & (2.2 \%) \\
1,760 & (3.3 \%)\end{array}$ \\
\hline - Paramaribo & 1791 & c. $8,000(68.0 \%)$ & $2,000(17.0 \%)$ & $1,760(15.0 \%)$ \\
\hline - Plantations & 1774 & $56,834(98.4 \%)$ & $914(1.6 \%)$ & \\
\hline Berbice & 1796 & $8,232(88.6 \%)$ & $860 \quad(9.3 \%)$ & $200 \quad(2.2 \%)$ \\
\hline Esseq./Demerara & 1796 & $28,000(89.3 \%)$ & $2,700 \quad(8.6 \%)$ & $650(2.1 \%)$ \\
\hline Tobago & 1665 & c. $7,000(84.8 \%)$ & $1,250(15.2 \%)$ & \\
\hline Curaçao & 1720 & $2,238(55.9 \%)$ & c. $1,720(42.9 \%)$ & $48 \quad(1.2 \%)$ \\
\hline - Willemstad & 1789 & $5,419(46.9 \%)$ & $3,507(30.4 \%)$ & $2.617(22.7 \%)$ \\
\hline - Countryside & 1789 & $7,445(78.8 \%)$ & $903(9.6 \%)$ & $1,097(11.6 \%)$ \\
\hline Bonaire & 1806 & $364(38.5 \%)$ & $72(7.6 \%)$ & $509(53.9 \%)$ \\
\hline Aruba & 1816 & $370(21.4 \%)$ & $210(12.1 \%)$ & $1,150(66.5 \%)$ \\
\hline St. Eustatius & 1790 & $4,944(63.1 \%)$ & $2,375(30.3 \%)$ & $511 \quad(6.5 \%)$ \\
\hline St. Maarten & 1790 & $4,226(75.9 \%)$ & $1,151(20.7 \%)$ & $194(3.5 \%)$ \\
\hline Saba & 1790 & $564(43.4 \%)$ & $730(56.1 \%)$ & $7(0.6 \%)$ \\
\hline New Netherland & 1664 & c. $400 \quad(5.3 \%)$ & c. $7,000(93.3 \%)$ & c. $100(1.3 \%)$ \\
\hline - New Amsterdam & 1664 & c. $300(12.6 \%)$ & c. $2,000(84.2 \%)$ & c. $75 \quad(3.2 \%)$ \\
\hline
\end{tabular}

Sources: Gold Coast: Numbers for 1645 based on Ruychaver (Dec. 1, 1645) as discussed by Ratelband (1953:lvii$\mathrm{xci}$ ), including the personnel on four coastal vessels based at Elmina; eighteenth-century figures based on Goslinga $(1985: 51,57)$ and Feinberg $(1989: 35,65,85)$ who estimates averages of 253-257 European WIC personnel between 1700 and 1760, and states that there is no consistent information on the numbers of visiting traders, seamen, or people waiting to go the New World; fort Elmina consists of the castle São Jorge Da Mina and fort Coenraadsburg; Dutch Brazil: Numbers for Pernambuco are tentative estimates based on various scholars, given in Schalkwijk (2005:48-49), with the Europeans divided into 30,000 Portuguese, 12,000 Dutch-Europeans and 1,500 Jews. Estimates suggest another 25,000 in the capitanias of Itamaracá, Paraíba, Rio Grande do Norte, and Ceará; Suriname: 1738 slave population is based on Hoogbergen's (1992:10) figure for 1728 and his estimated growth of the slave population thereafter, while the white and free black population are from Van Lier (1977:71); 1795 slave population is from Van Stipriaan (1993:311), but the white and free black and mulatto populations are taken from 1791 (Van Lier 1977:70, Goslinga 1985:364); Van Stipriaan (1993:314) gives a total free population in 1795 of 4,953, and it would not be unreasonable that this growth of 293 people over four years was largely made up of free Blacks and Mulattoes (numbers seem to correspond with Van Lier here); Paramaribo figures for 1791 from Van Lier (1977:23, 71) - although the 8,000 slaves of Paramaribo seems very high when compared with the low number in Van Stipriaan (1993:311); Plantation figures are from the same sources and the choice has been made (see 1791) to leave all free Blacks and Mulattoes out of this count; the military personnel has often been left out of these population figures, even though they could amount to as many as 1,950 in 1774 . Berbice: Goslinga (1985:439) and Enthoven (2004:157-58); Essequibo and Demerara: Van der Oest (2003:329); Goslinga (1985:439) gives 21,259 slaves for 1790, which sounds plausible given the heavy British imports in the 1790s; the split between Essequibo and Demerara was for 1796 (8,000/20,000); Tobago (Nieuw Walcheren): Roos (1992:113); Curaçao: 1720 in Goslinga (1985:102), Van Goor (1994:119); Klooster (1999:508) for the free Blacks (48), although suggesting that they made up $5.6 \%$ of the island population is impossible, and he must have been thinking of percentage of the free population only: in 1709 the free white population of Willemstad was 687 (Rupert 2006:147), adding the 233 WIC personnel and military from 1720 (Goslinga 1985:103), one comes close to Klooster's percentage. For the free white population of Curaçao in 1720, Van Goor (1994:119) states that there 
were 220 employees of the WIC, and 500 free burgher families, and that we should multiply this number by 3-4, which would mean around 2,000 European colonists - I have chosen the factor 3, based on Rupert (2006:147); 1789 in Klooster (1994:289; 1998:61); Klooster logically assumes that free servants (846) were all White, as the free non-white population $(3,714)$ was listed as a separate category. These numbers differ slightly from Enthoven (2004:159), who calculates 3,814 Europeans, 2,450 Free People of Color, and Van Goor (1994:119) who has lower figures; Bonaire: Goslinga (1990:130); Aruba: 1816 in Enthoven (2004:158); St. Eustatius, St. Maarten, and Saba: Goslinga (1985:131, 138, 152); New Netherland: Jacobs (1999:67, 253, 267-68); Jacobs (1999:417 n.13) considers Van den Boogaart's (1986) estimate of a total population of 6,030 in 1664 far too low, especially because he hardly takes natural growth into account, and this was certainly the case for family migration to a fairly healthy climate. For the black and slave population estimates of New Amsterdam, see Harris (2003:21-22) and many other publications on this topic. Of course, such estimates could quickly alter, for instance, with the arrival of 290 slaves from Africa just before the British take-over, even though most of those slaves were sold onward to Chesapeake tobacco plantations. Native American populations are excluded from these estimates, though some lived among the Dutch communities, of course.

* Doortmont \& Smit (2007:325) give the following Dutch castles and forts (and the African towns) on the Gold Coast during the era of the slave trade: Fort Crèvecoeur (Accra) 1649-1868; Fort Good Hope (De Goede Hoop, Senya Beraku) 1705-1868; Fort Patience (Lijdzaamheid, Apam) 1697-1868; Fort Amsterdam (Abandze, Kormantin) 1665-1868; Fort Nassau (Mouri) 1612-1868; Cabo Cors (Cape Coast) 1660s; Castle St. George d'Elmina (Elmina) 1637-1872; Fort Coenraadsburg on St. Jago Hill (Elmina) (1637) 1660s-1872; Fort Vredenburg (Dutch Komenda) 1689-1872; Fort St. Sebastian (St. Sebastiaan) (Shama) 1638-1872; Fort Orange (Oranje) (Dutch Sekondi) 1670s-1872; Fort Witzen (Takoradi) 1680s-1872; Fort Batenstein (Butre) 1656-1872; Fort Dorothea (Akwida) 1717-1872; Fort Gross Friedrichsburg (Hollandia) (Princes' Town/Pokesu) (1717) 1725-1872; Fort St. Anthony (Axim) 1642-1872; Fort Ruyghaver (Ankobra River) 1654-1659.

Native Americans, control of these slaves was of primary concern to the colonial order. From the lower U.S. South all the way to central Brazil, African slaves always made up more than half of the total population and their labor was indispensable to the raison d'être of these societies: the plantations. The Dutch era in Brazil and their later settlements on the Wild Coast (Suriname, Berbice, Essequibo, and Demerara) certainly fit this mold. The major insular Caribbean colonies of the Dutch (Curaçao, St. Eustatius, St. Maarten) possessed slightly lower percentages of slaves, primarily because they did not fully adhere to the classic American plantation model. The islands were either too small or the climate too arid for plantation agriculture to be truly viable. They were still characterized by "black majorities," partly because of their specific historic roles in the transatlantic slave trade, and partly because European immigrants generally avoided such unhealthy tropical climates. New Netherland easily came closest to resembling the natural environment of Western Europe, and accordingly witnessed a sizeable family migration of European colonists and had no strong demand for African slaves, except in trading them onward to more plantation-oriented colonies.

While slave populations in most Dutch VOC possessions were substantial as well, the comparison with the American colonies completely falls apart if we take the surrounding indigenous populations into account. The "Natives" in the Indian Ocean World formed the true "black" or non-European majorities, and as such were both respected and feared by the European colonizer. Their indigenous production and extensive Asian trade networks allowed European colonists to limit direct control to fortified trading posts and their immediate 
hinterlands. Of course, they had but very little choice in this matter. In this maritime network of colonial towns, slaves formed a unique element occupied with serving the Dutch inner circle: they worked on the docks, erected fortifications, tended to Company garden plots, functioned as artisans, and complemented the European households as domestic servants, concubines, or even as future wives. But they were almost never involved in commercial agriculture for the European market. In the Indian Ocean World, commercial production remained squarely in the hands of indigenous societies.

Slaves were thus numerically important only if we concentrate on the various VOC ports, from Batavia to Colombo, Cochin to Cape Town. Their demographic impact gradually loses significance if we extend the concentric circle around those colonial towns (Raben 2008). The only WIC settlement that closely resembled this pattern was, quite tellingly, Elmina on the African Gold Coast (current-day Ghana). ${ }^{62}$ The few hundred WIC servants and their Company slaves who resided in and around the two forts were insignificant when placed against the demographic and military strength of Elmina town on the African mainland, with a population (including slaves) fluctuating somewhere between 12,000 and 16,000 during the eighteenth century (Feinberg 1989:65, 85; Van Kessel 2002:25, 101). Friendly relations with the local rulers were, understandably, an absolute priority to the Dutch.

Slavery in the European trading posts across the Indian Ocean World had a decidedly urban and domestic character. Slaves performed a much wider variety of service-oriented tasks than their "colleagues" in the Americas, who were primarily occupied with plantation production of an industrial nature. In their attempts to estimate the relative harshness of the slave's condition, historians have often judged urban slavery to be rather mild. Such a judgment is primarily based on the harsh and monotonous working conditions that field slaves encountered, but also on the limits of social control in the city and the general mobility that characterizes most sea-ports throughout history. The colonial environment and its economy were thus of fundamental importance in defining the lives of the slaves.

In an attempt to assess the relative importance of slavery, M.I. Finley (1968) made a now classic distinction between "societies with slaves," encompassing most civilizations throughout human history, and a few historic "slave societies," in which the entire socioeconomic structure was based on slavery as a mode of production. His definition of "slave society" was a very narrow one and, beside his fascination with classical slavery, fitted only the European plantation colonies in the Americas. Historically,

62. The Dutch forts on the African coast were unique in that they, according to Feinberg (1989:36), only consisted of Company employees and possessed no European free burgher class; a similar situation - though for different reasons - developed in the VOC post of Dejima in Japan. 
the rise of the "plantation complex" was firmly based on the production of sugar for the expanding European market. All the major importers of slaves in the Americas, from Brazil in the sixteenth to Cuba in the nineteenth century were essentially addicted to this combination of "sweetness and power" (Mintz 1985). ${ }^{63}$ The plantation colonies of the Dutch, New Holland (Dutch Brazil) in the first half of the seventeenth century and Suriname and the other Wild Coast settlements thereafter, did not significantly differ from this pattern. Suriname had 171 sugar plantations by 1713 (Van Stipriaan 1993:33), but underwent a dramatic intensification of plantation agriculture during the eighteenth century, as the production of coffee began surpassing that of sugar. This explains in large part the increased volume of the Dutch transatlantic slave trade during the middle decades of the century. Table 9, based on the most thorough quantitative study of Suriname during its last hundred years of slavery, shows the development of this commercial plantation sector.

The other Dutch plantation colonies on the Wild Coast grew even more dramatically during the second half of the eighteenth century, though this expansion was mainly instigated by British and North American planters and merchants. When the English occupied these colonies during the Napoleonic era, the slave population of Essequibo and Demerara quickly increased from 28,000 in 1796 to circa 60,000 slaves in 1806, working a total of 700 plantations (Van der Oest 2003:329). They produced the same commodities for the European market as nearby Suriname and in fairly identical patterns, with sugar and coffee closely rivaling each other, followed at a large distance by cotton and then cacao.

Sugar cane never wavers too far from the equator but, as its history shows, experienced a clear westward migration across the globe. Sugar production was an essential feature of several economies around the Indian Ocean World, but it never became so closely connected to the tragedy of slavery as in the greater Caribbean. Sugar plantations around Batavia and on Taiwan during the VOC period, for example, may occasionally have turned to slave labor as well, but they were predominantly run by Chinese merchants who imported cheap "coolies" from China for the drudgery ${ }^{64}$ Later, during the Cultivation

63. The powerful role of sugar is sometimes overlooked when focusing on slavery in the North American mainland, where tobacco and, in the nineteenth century, cotton were king. Only in the Mississippi River Delta of Louisiana sugar plantations operated, but this only goes to show that the cultivation of sugar cane is limited to unhealthy subtropical climates. Not surprisingly, slavery in the rest of the southern United States was exceptional considering that its slave population showed a positive natural growth and, as a result, high levels of creolization. Even within the South, slave life and culture manifested itself in different ways according to the agricultural organization (tobacco, rice, indigo) of the colonies; see both Morgan 1998 and Berlin 1998.

64. The VOC on Formosa mainly profited indirectly, by taxing the Chinese on almost all their economic activities, even on the right to collect these taxes. In 1651, at a time 
Table 9 Suriname plantation slaves producing for the export market 1750-1863

\begin{tabular}{lcccc}
\hline Plantation sector & Year & $\begin{array}{c}\text { Number of } \\
\text { plantations }\end{array}$ & $\begin{array}{c}\text { Total slaves } \\
\text { (average per plantation) }\end{array}$ & $\begin{array}{c}\text { Field slaves (number per } \\
\text { plantation) and \% of total }\end{array}$ \\
\hline Sugar & 1750 & 141 & $19,008(135)$ & $9,835(70) 52$ \\
& 1770 & 111 & $16,584(149)$ & $8,411(76) 51$ \\
& 1790 & 102 & $12,232(120)$ & $5,243(51) 43$ \\
& 1810 & 100 & $10,108(101)$ & $4,196(42) 42$ \\
& 1825 & 95 & $12,352(130)$ & $5,925(62) 48$ \\
Coffee & 1862 & 86 & $19,789(230)$ & $7,876(92) 40$ \\
& 1750 & 225 & $16,029(71)$ & $9,332(41) 58$ \\
& 1770 & 295 & $37,179(126)$ & $20,087(68) 54$ \\
& 1790 & 248 & $26,710(108)$ & $12,390(50) 46$ \\
& 1810 & 235 & $21,968(93)$ & $10,668(45) 48$ \\
Cotton & 1825 & 178 & $17,363(98)$ & $8,132(46) 47$ \\
& 1862 & 37 & $3,892(105)$ & - \\
Cacao & 1825 & 73 & $8,290(114)$ & $4,145(57) 50$ \\
\hline
\end{tabular}

Source: Van Stipriaan 1993:128-44, 438-39.

System on Java, the Dutch began forcing native labor into sugar production, often through more indirect, feudal means. Only the tiny island of Mauritius showed a glimpse of slave-based sugar production during its Dutch occupation, but its true maturation as a plantation colony took place later, during the eighteenth and nineteenth centuries. The main reason why the Mascarenes eventually developed according to a Caribbean pattern was because they were largely uninhabited and more or less "open" to European colonization.

The closest the Dutch came to slave-based plantation agriculture in the Indian Ocean World was in the Moluccas (Maluku), the famous "spice islands" located a thousand miles to the east of the VOC capital of Batavia. But even here, specific local conditions and historic events were of prime importance in the development of slavery. On Ambon and Ternate, where the Dutch had defeated the Portuguese at an early stage (1605), the production of cloves remained in the hands of the large indigenous population, sometimes aided by local or imported slaves. The VOC merely arranged the fixed purchase and shipment of these cloves and frantically oversaw the coveted monopoly on the spice, for example by deploying expeditions to extirpate

when Dutch Taiwan finally became profitable for the Company, the Chinese produced $4,400,000$ pounds of sugar, while the average sugar yields for that period was between approximately one and two million kilos annually (Van Veen 1996:71, 77). Van Veen states that "the process of colonization of Formosa was very similar to what had happened in South America [as in Spanish America?] and what would take place more than two hundred years later in Africa [during its colonial era]." 
clove trees in areas that were too difficult to control (the so-called hongi expeditions). Its headquarters in the Ambonese archipelago, the city of Kota Ambon, certainly depended on the services of an extensive - and almost entirely imported - slave population, but few of them were directly occupied with the production of cloves (Knaap 1991).

The Banda islands to the south, the sole place in the world to grow nutmeg trees at the time, could perhaps have developed in a similar direction as Ambon. The indigenous population made a comfortable living by a "not especially arduous mode of horticulture" (Hanna 1978:6-9). Nutmeg and its by-product mace were accordingly sold to various competing Asian and European merchants. But the VOC demanded exclusive rights to these spices and, through a series of ruthless expeditions, took hold of the island group in the early seventeenth century. Both fierce resistance by the Bandanese against such a monopoly, and Dutch acknowledgment that these islands were in fact small and isolated enough to be controlled directly, contributed to one of the most tragic chapters in Dutch colonial history. ${ }^{65}$ After the Bandanese population had almost been annihilated, the Company resumed the production of nutmeg and mace through a system of Dutch planters (perkeniers) and imported slaves working the small-scale plantations (perken). The Banda islands under the Dutch became, in the words of one historian, "nothing less than a Caribbean cuckoo in an Asian nest" (Loth 1995:35).66

Yet what the VOC created on Banda in the 1620s was unique due to its rigid monopolistic character. The productive area of the three main islands were divided into 68 perken of equal size (33 on Lonthor, 31 on Ai, and 3 on Neira, where the Company headquarters were located), and each perk was provided with 25 slaves whom the VOC delivered at a fixed price of 40 rijksdaalders (96 guilders) each (Hanna 1978:59-60). Most of these starting conditions remained unchanged for over two centuries. For example, the loss of 1,529 slaves in several epidemics in 1693, 1702, and 1715 was still calculated at 40 reaal a piece (Hanna 1978:55). The stationary character of Banda stands in stark contrast with the market fluctuations affecting the

65. Hanna (1978:3) estimates the size of the island group at 1/25,000 of the entire Indonesian archipelago. The famous J.P. Coen headed the final conquest of the islands in 1621 , and it is often suggested that this was revenge for the massacre of a group of VOC officials by the locals in 1609 , events a young Coen probably witnessed first-hand. A report by VOC official Jacques l'Hermité in the early 1610s (De Jonge 1865:380-94) already suggested a "final solution" of similar proportions.

66. I generally agree with Loth's treatment of Banda under the Dutch as a Caribbean plantation model. It would be interesting to see if the architects of the perkenier system referred to concrete examples from the European colonization of the New World. At the beginning of the VOC experiments with perken on Ai in 1616, the Caribbean plantation system was still in a developmental stage, but perhaps Spanish colonization or, more likely, Portuguese sugar captaincies in Brazil provided the Dutch with a model. 
American plantation sector. The monopoly on nutmeg and mace enabled the VOC to keep both prices and production stable. In the 1630s, the Company had extirpated all nutmeg trees on the island of Run, for fear of possible resettlement by the English. They could easily have expanded cultivation to Run in the late $1660 \mathrm{~s}$, when Great Britain officially relinquished all its prior claims on the island. ${ }^{67}$ But they felt no need to do so until 1862, when new perken were laid out on Run (Hanna 1978:66). ${ }^{68}$ The monopoly thus ensured that the slave population on the perken "stagnated" between 2,000 and 3,000 throughout the colonial period. Even though they produced for the European export market, there was no pressure to overwork the slaves as was often the case in the highly competitive Caribbean plantation sector. ${ }^{69}$

At the Cape the demographic and military weakness of the indigenous pastoral societies also allowed the Dutch to colonize more according to an American settlement pattern. Fortunately for the slaves, a moderate climate prevented any large-scale commercial plantation agriculture. That slavery nevertheless became such an important feature of the Cape economy has everything to do with its geographic location in the middle of two large slavetrading networks. In the early stages of its development, there were still signs that the colony would follow a pattern similar to New Netherland, relying predominantly on immigrant labor - either indentured or not - from Europe.

If slave laboring conditions on Banda and in the rural Cape districts were exceptional compared to most other VOC possessions, the lower Dutch Caribbean islands were an aberration to the general West Indian pattern. Though the WIC made several efforts to establish sugar and tobacco plantations on Curaçao, the arid climate generally confirmed earlier Spanish observations that these were, at least from the perspective of commercial agriculture, islas inútiles. Curaçao and its port Willemstad acted as a naval base, a slave-trading emporium, and a free haven for illicit trading with the Spanish Main, but never as a slave-based plantation economy producing for the European market. Looking at their roles in the colonial economy, slaves on Curaçao often performed tasks quite similar to those of slaves in the VOC trading posts.

67. As part of the Peace of Breda (1667) which settled the Second Anglo-Dutch Naval War (1665-1667). In this peace settlement the English took over New Netherland (New York), while the Dutch in turn claimed Suriname, a swap that has often been ridiculed with the benefit of hindsight, but at the time cannot have seemed too disadvantageous.

68. The termination of the monopoly was officially decreed on April 31 [sic], 1864, but only became effective in 1873 (Hanna 1978:105).

69. To state that working conditions of slaves are either good or bad should not automatically lead to conclusions regarding their general treatment, but it certainly can be a useful indicator. 
From New Amsterdam to Cape Town, from Elmina to Colombo, slaves in Dutch colonial towns were occupied with a great variety of work activities: building fortifications, loading and unloading ships, growing food for local consumption in Company gardens, being hired out as urban artisans or apprentices, serving European families as domestic servants, or transient sailors and soldiers as prostitutes. There was always something to do in the bustling trading posts of the Dutch colonial empire, and slave labor was used accordingly. One gets a vivid sense of this diversification of work from a list of runaway slaves that left Curaçao between 1729 and 177570: among the 500 male runaways, there were 129 field slaves $(25.8 \%), 82$ seamen $(16.4 \%), 47$ carpenters (9.4\%), 32 fishermen $(6.4 \%), 30$ shoemakers $(6.0 \%)$, but also 16 cooks $(3.2 \%)$ and 15 bakers $(3.0 \%), 15$ musicians $(3.0 \%)$, and, finally, of bricklayers and tailors 14 (2.8\%) each; among the 85 female slaves that escaped, traditional household tasks prevailed, with laundresses $(17.6 \%)$, seamstresses $(14.1 \%)$, knitters (11.8\%), vendors (10.6\%), and domestic slaves $(9.6 \%)$ all looking to improve their condition (Klooster 1994:285). Besides showing the variety of slave labor, the list demonstrates that seemingly preferable working conditions were no guarantee for a slave's acquiescence; in fact, the lure of freedom might have been greater for those who had already received a taste of it.

This list mainly reflects slavery on Curaçao in the post-asiento era, after its economy underwent a dramatic transition. Between the 1660s and 1710s, a sizeable contingent of Company slaves was employed in the transit slave trade. The "garden slaves" (tuinslaven) attending the Company plantations were primarily occupied with cattle breeding and the production of sorghum to feed the "trade slaves" (negotieslaven) awaiting transport to arguably harsher and more monotonous labor conditions elsewhere. From 1700 to 1715 , the WIC owned an average total of 618 slaves on the island, but after the asiento contracts fell to the English, the Company reduced its slaves to 206 in 1718 and to only 181 in 1720 (Jordaan 1999:482).

It was fairly common for both the WIC and VOC to downsize their slave holdings after large initial infrastructure and public works projects had been completed. ${ }^{71}$ Such slaves were usually sold on the private market or transported elsewhere. Over time, the share of private in relation to Company slaves residing in a colony therefore grew invariably larger. But the situation on Curaçao during the 1710s was more complex. Slaves continued to arrive from Africa, but there were hardly any buyers available. ${ }^{72}$ In the first half of

70. The most likely destination was Coro, on the Venezuelan coast. Since this kind of marronage was always by boat, it is no wonder that sailors and fishermen were well represented here. For more on this maritime marronage, see Rupert 2006.

71. For a good example of this in the VOC town of Colombo, Ceylon, see Knaap 1981: 96-98.

72. This episode - slaves arriving, but no buyers and no food available - shows remarkable resemblance to the situation in Dutch Recife around 1645. 
1715, an average of 64 trade slaves awaited further sale, and this number rose to an average of 339 in the second half of that year, and peaked at 931 slaves in April of 1716, before gradually going down to a more manageable size at the end of 1717 (Jordaan 1999:482). Combined with the already precarious food situation, caused by recent droughts, this led to substantial tensions on the island. ${ }^{73}$ Looking for solutions, the governor attempted a haphazard "plantation-experiment" on Aruba and to send slaves to Bonaire as well (Jordaan 1997), perhaps more with the intent to ease the pressure on Curaçao than honestly believing that decent profits could be made.

At a certain point the slave-to-food ratio on the island became so unstable that old and sick slaves were manumitted and were "free" to fend for themselves. Apparently, the material costs to maintain such slaves had become higher than the economic returns of their labor, and any paternalist ideology went quickly out the door. There are more cases of manumission as a strategy toward cost-effectiveness among Dutch colonists. For example, when Batavia was struck by a leprosy epidemic in the 1670 s, owners parted with their slaves at such an alarming rate that around 1684 a total of 1,366 people were dependent on poor relief from the church, an estimated 70-80 percent of them single women and their children (Niemeijer 2000:181). And in New Amsterdam, the WIC granted freedom to its first generation of loyal slaves, those that helped build the foundations of Manhattan and worked its Company gardens, but freedom came with such stipulations that manumission seemed more like a calculating than a truly honorable deed. While the letting go of an old or incapacitated slave is likely as old as the institution of slavery itself, large-scale manumissions for reasons of - relative - profitability have, as far as I know, seldom occurred in plantation economies where slave labor was dearest. ${ }^{74}$

Individual manumission was, of course, often the result of intimate bonds and long-standing relationships between masters and slaves. Such bonds had a better chance of developing and thriving in the closed settings of the private European households where domestic slaves spent most of their days. Their actual tasks may not have differed much from those performed by servants and maids in Europe, but their legal status did and with it their vulnerability in face of their master and mistress. Depending on the personal whims of their owners, the fortune of domestic slaves fluctuated between the extremes of freedom and upward social mobility on the one hand, or chronic mental

73. Jordaan 1999 gives a fascinating in-depth account of these conditions, connecting them - quite convincingly - to the slave rebellion of trade slaves on the St. Maria plantation in 1716.

74. Suriname witnessed regular manumissions of old and incapacitated slaves, but to prevent this from becoming a nuisance to society specific limitations were set in 1733 , and from 1788 on, slave owners had to pay one hundred guilders for a manumission letter. I thank Henk den Heijer for bringing this to my attention. 
and physical abuse and death on the other. As they were considered part and parcel of the households, their social isolation could be debilitating.

Domestic slavery was perhaps the central feature of Dutch colonial society in the Indian Ocean World. There is ample evidence suggesting the preponderance of slavery among the free burgher and Company servant households of some of the major colonial towns in the VOC domain. The average slave holdings of these households fluctuated roughly between 4 to 6 slaves. ${ }^{75}$ But if we focus in on the households of European background or those belonging to the Company elite, the average slave holdings significantly increase (Knaap 1981:94; 1991:123). While some of the larger private slave holdings hired out slaves for profit or participated in the local slave trade, it can be surmised from these figures that most European households contained more domestic labor than was strictly necessary. In some cases this may have resulted in a lighter overall work load for the slaves, or more "uneconomic" and "eccentric" tasks, such as playing in a private orchestra. To emphasize their social status in the colonial world, the local European elite apparently did not shy away from conspicuous consumption, in sharp contrast with the Calvinist "embarrassment of riches" that Simon Schama (1987) discerned in the seventeenth-century Dutch Republic.

The belief that European colonists in the tropics were easily corrupted by greed, luxury, and slavery has been widely disseminated since the early days of travel writing. A recent analysis (Van den Boogaart 2000) brilliantly demonstrates early Dutch concerns that Europeans would degenerate as a result of the exotic climate and guilty pleasures of Asia, including their dependence on servile labor. Nicolaus de Graaff's oft-cited comment that the wives of VOC officials "are waited on like princesses, and some have many male and female slaves, who have to be alert as watchdogs day and night" had - certainly from a metropolitan perspective - a very negative sound to it (Knaap 1981:93). ${ }^{76}$ Moreover, judging by the scattered anecdotal evidence, these wives were often susceptible to power abuse, with their private slaves as the prime victims. Since domestic slavery was so prevalent in these colonial societies, it logically follows that the female head of the household carried the main burden for managing these slaves. But perhaps the brunt of contemporary criticism was also reserved for her because she constituted the most "exotic" element in the European power structure; in other words, it may

75. Based on Cochin (Wolff 1992:50-51, 71-72), Colombo (Knaap 1981:88, 93), Kota Ambon (Knaap 1991:121, 124), and Malakka (Ketelaars 1985:69-71).

76. Knaap (1981:93) suggests that, owing to the presence of many households with no or only a few slaves, "descriptions of women living like princesses should be treated with caution," yet he himself gives fairly high average slave holdings for the European households. Ketelaars (1985:72) points out that De Graaff was singling out the wives of Company servants and that his comments might therefore have more validity than Knaap submits. 
have been psychologically convenient to blame cruelty and overindulgence strictly on the Asian character of colonial society. ${ }^{77}$

The dearth of European women was a problem in European colonial expansion in general, but particularly so in the VOC domain. For example, the town of Malakka counted a total of 558 European men in 1678, but only 26 European women, of whom 24 were married to Company servants (Ketelaars 1985:68). Elsewhere the situation was hardly different. Consequently, the highly imbalanced sex ratios could only be overcome by appealing to local women, and racial intermixture developed almost hand in hand with the colonization process. ${ }^{78}$ The stock of young native and mestizo women rose dramatically, and through them the mixed outlook of VOC settlements became even more pronounced (Knaap 1981, Singh 2007:105-8). Of course, there was plenty of interracial mixing in the American colonies as well. But what set the Asian developments apart was that by marrying Company servants and free burghers native and mestizo women and their legitimate offspring joined the ranks of the colonial elite. To emphasize her newly acquired "European" identity, it is quite conceivable that the mestizo wife sometimes acted the part, by treating her domestic slaves, who often had a similar ethnic background, in an extremely deprecating manner.

This tension within the household may have been further exacerbated by the fact that female slaves were not excluded from marrying European men either. Yesterday's slave could be today's concubine and tomorrow's wife. Falling into favor with her European master or one of his friends, she could - after the required manumission and conversion to Christianity - legally marry him and acquire the coveted European status (Ketelaars 1985:61, 67). The Bali slave trade was particularly notorious for providing both Chinese and European men with desirable concubines and potential future marriage partners. Consequently, choice female slaves often commanded higher prices than their male counterparts on Asian slave markets - in contrast with the Americas where strong adult men were preferred for the hard field labor on the plantations.

Considering the substantial social mobility involving a marriage between a master and his former slave, it is not difficult to conceive that under the circumstances most of these women felt "lucky" and submitted willingly to such an ordeal. There do not appear to be many scholarly discussions about the history of the sexual abuse and rape of these concubine slaves, a most sensitive topic in the historiography of slavery in the Americas. Even in the

77. For a recent interpretation of the European representation of Asian women in Dutch travel literature, see Van de Walle 2001.

78. Knaap (1981:90) makes the counterfactual statement that "if only free males are taken into account, Colombo was much less of an 'ethnically mixed town' than colonial settlements of the period are sometimes considered to be." 
best-case scenario, when a female slave was manumitted together with her children and generously taken care of by her former master, there were - as far as I know - no cases of legally sanctioned marriages between the two in the New World; they were in fact prohibited by law. In the American colonies, the ranks of white Europeans were closed for ex-slaves.

In Degler's (1972) classic but controversial study comparing race relations in Brazil and the U.S. South, he characterized the former as more flexible and lenient because of the so-called "mulatto escape hatch": lightskinned African Americans of considerable means and education and with well-established social connections were able to escape the black mass and perhaps enter the dominant caste. Elsewhere, in various parts of the former Spanish Americas, mestizaje - not white, not red, not black, but a mixture of them - is often proclaimed to be the core national identity. To some extent these are highly romanticized and nationalistic representations that emerged only after emancipation and decolonization. At the same time these IberianAmerican colonies do show some of the demographic dynamics of the Indian Ocean World, with more sizeable indigenous populations and, perhaps as a result thereof, a greater tolerance for interracial mixing and a better treatment of slaves. At the risk of resurrecting an awkward term, one could perhaps state that Asian women, by marrying Dutch or European men, benefited from a "mestizo escape hatch." But we should be extremely cautious in bringing uniquely American concepts of race into a discussion on the Indian Ocean World. The various ethnic groups serving as slaves to the Dutch and other Europeans in Asia were generally represented by much larger nonslave populations, and were consequently unburdened by a stigma of slavery or a somatic-norm image from which they felt pressured to escape.

The key to unlocking race relations in the Americas - it has been suggested before - is rooted in the legal and social positions accorded to free Blacks and Mulattoes. In the plantation colonies of the greater Caribbean, the large black majorities and the small European master class in time forced the creation of a three-caste system, with an intermediate buffer group of loyal house slaves, free Blacks, and free Mulattoes who sometimes aided, but were never fully accepted by the white elite. On Curaçao, the relative size of the free black/mulatto population expanded dramatically during the eighteenth century, largely because of its decreased importance in the transatlantic slave trade. The percentage of the free black/mulatto population was larger than on any other Caribbean island (Klooster 1999:508) and before the abolition of slavery it had become the dominant identity, amounting to 43.5 percent of the population in 1833 (Klooster 1994:288). As the slave-free dichotomy became increasingly vague, white residents began invoking modern pseudoscientific ideologies of race to ensure that, if no longer slaves, free Blacks were not entirely free either (Oostindie 2000:56-59). 
Where the European colonial population was stronger and the sex ratios more balanced, as in the settlement colonies of North America and South Africa, over time a more rigid line was drawn between Whites and Blacks, ultimately leading to tragic legal constructions such as Jim Crow segregation and apartheid to prevent, or at least tightly channel, interracial contact. Over the past two decades historians have begun unearthing what Gary Nash (1995) has called the "hidden history of mestizo America," to show that more social openness and flexibility existed in earlier times. But their strenuous mining of the earliest colonial sources only appears to confirm that such mixed relationships quickly became taboo in North America. They also point out that racial exclusivity grew ever stricter over time, as the white settler population continued to increase and the abolition of slavery allowed a much more virulent type of racism to develop.

As a consequence of this strong racial identification of American slavery, the multiple identities of slaves, Blacks, and Africans became closely intertwined and were - in most cases - immediately visible. Over time it helped create a resilient group identity that is still very much alive today, albeit in various gradations. Naturally, this has great implications for the historic development of slave community and culture, the frequency of slave resistance and rebellion, and ultimately for the willingness to remember and identify with a past of slavery.

In the Indian Ocean World such empowerment in the face of adversity was noticeably absent among the slaves. Slavery and freedom were never as strongly opposed as in the Americas anyway, with many intermediate categories that were nearly indistinguishable from slave status. In fact, the predominance of domestic slavery in European colonial households presented the individual slave with opportunities to "work the system" to their personal advantage, opportunities that may have never sprung up had they not become slaves in the first place. Furthermore, manumission did signify, in decided contrast with the Americas, a clear break with the slave "community." The lack of one specific racial, ethnic, or religious identity that was imprinted on either the slave or the master prevented the growth of a common culture and solidarity among slaves. The slave rebellion at the Cape in 1760, for example, was primarily rooted in the religious (Muslim) and ethnic (Bugis) background of the participants, who formed quite a uniform group considering that the Cape Colony has been labeled the most diverse slave society in the world (Koolhof \& Ross 2005). In whatever form or shape freedom eventually came - through individual manumission, by flight, or in a general emancipation - the ex-slave of the Indian Ocean World gradually disappeared in its massive, motley crowd. Therein lies the key explanation as to why the history of slavery in the Indian Ocean World has been neglected thus far. If we want to get a fuller picture of Dutch colonial slavery, it is entirely up to the historians to unravel this story, because no one else will. 


\section{REFERENCES}

AMUSSEN, SUSAN DWYER, 2007. Caribbean Exchanges: Slavery and the Transformation of English Society, 1640-1700. Chapel Hill: University of North Carolina Press.

BARENDSE, R.J., 1995. Slaving on the Malagasy Coast, 1640-1700. In Sandra Evers \& Marc Spindler (eds.), Cultures of Madagascar: Ebb and Flow of Influences. Leiden, the Netherlands: International Institute for Asian Studies, pp.137-55.

BERLIN, IRA, 1996. From Creole to African: Atlantic Creoles and the Origins of AfricanAmerican Society in Mainland North America. William and Mary Quarterly 53:251-88.

—, 1998. Many Thousands Gone: The First Two Centuries of Slavery in North America. Cambridge MA: Belknap Press.

BLACKBURN, ROBIN, 1997. The Making of New World Slavery: From the Baroque to the Modern, 1492-1800. New York: Verso.

BLAKELY, ALLISON, 1993. Blacks in the Dutch World: The Evolution of Racial Imagery in a Modern Society. Bloomington: Indiana University Press.

BOOGAART, ERNST VAN DEN, 1992. The Trade between Western Africa and the Atlantic World, 1600-90: Estimates of Trends in Composition and Value. The Journal of African History 33:269-85.

—, 2000. Het verheven en verdorven Azië. Leiden: KITLV Press.

— , \& Pieter C. EMMER, 1979. The Dutch Participation in the Atlantic Slave Trade, 1596-1650. In Henry A. Gemery \& Jan S. Hogendorn (eds.), The Uncommon Market: Essays in the Economic History of the Atlantic Slave Trade. New York: Academic Press, pp. 353-75.

CAMPBELL, GWYNN (ed.), 2004a. The Structure of Slavery in Indian Ocean Africa and Asia. London: Frank Cass.

—, 2004b. Abolition and its Aftermath in Indian Ocean Africa and Asia. London: Frank Cass.

CHRISTOPHER, EMMA, 2006. Slave Ship Sailors and their Captive Cargoes, 1730-1807. Cambridge: Cambridge University Press.

— et al. (eds.), 2007. Many Middle Passages: Forced Migration and the Making of the Modern World. Berkeley: University of California Press.

CURTIN, PHILIP D., 1969. The Atlantic Slave Trade: A Census. Madison: University of Wisconsin Press.

DAALDER, REMMELT et al. (eds.), 2001. Slaven en schepen: Enkele reis, bestemming onbekend. Leiden, the Netherlands: Primavera Pers.

DAVIS, DAVID BRION, 2000. Looking at Slavery from Broader Perspectives. The American Historical Review 105:452-66. 
DEGLER, CARL N., 1972. Neither Black Nor White: Slavery and Race Relations in Brazil and the United States. New York: Macmillan Co.

DOORTMONT, Michel R. \& JinNA SMIT (eds.), 2007. Sources for the Mutual History of Ghana and the Netherlands: An Annotated Guide to the Dutch Archives Relating to Ghana and West Africa in the Nationaal Archief, 1593-1960s. Leiden, the Netherlands: Brill.

DRESCHER, SEYMOUR, 1994. The Long Goodbye: Dutch Capitalism and Antislavery in Comparative Perspective. The American Historical Review 99(1):44-69.

EBERT, CHRISTOPHER, 2003. Dutch Trade with Brazil before the Dutch West India Company, 1587-1621. In Johannes Postma \& Victor Enthoven (eds.), Riches from Atlantic Commerce: Dutch Transatlantic Trade and Shipping, 1585-1817. Leiden, the Netherlands: Brill, pp. 49-75.

ELTIS, DAVID, 1993. Europeans and the Rise and Fall of African Slavery in the Americas: An Interpretation. The American Historical Review 98:1399-423.

—, 1994. The Relative Importance of Slaves and Commodities in the Atlantic Trade of Seventeenth-Century Africa. Journal of African History 35:237-49.

—, 1999. Slavery and Freedom in the Early Modern World. In Stanley L. Engerman (ed.), Terms of Labor: Slavery, Serfdom and Free Labor. Stanford CA: Stanford University Press, pp. 25-49.

—, 2000. The Rise of African Slavery in the Americas. Cambridge: Cambridge University Press.

—, 2001. The Volume and Structure of the Transatlantic Slave Trade: A Reassessment. William and Mary Quarterly 58:17-46.

EMMER, PIETER C., 1972a. De slavenhandel van en naar Nieuw-Nederland. Economischen Sociaal-Historisch Jaarboek 35:94-147.

—, 1972b. The History of the Dutch Slave Trade: A Bibliographical Survey. Journal of Economic History 32:728-47.

—, 2000. De Nederlandse slavenhandel, 1500-1850. Amsterdam: De Arbeiderspers.

ENTHOVEN, Victor, 2003. Early Dutch Expansion in the Atlantic Region, 1585-1621. In Johannes Postma \& Victor Enthoven (eds.), Riches from Atlantic Commerce: Dutch Transatlantic Trade and Shipping, 1585-1817. Leiden, the Netherlands: Brill, pp. 17-47.

—, 2006. Dutch Crossings: Migration between the Netherlands and the New World, 1600-1800. Atlantic Studies 2:153-76.

FEINBERG, HARVEY M., 1989. Africans and Europeans in West Africa: Elminans and Dutchmen on the Gold Coast during the Eighteenth Century. Philadelphia: Transactions of the American Philosophical Society.

FINLEY, M.I., 1968. Slavery. International Encyclopedia of the Social Sciences $14: 307-13$ 
Foner, Laura \& Eugene D. GenOVESE (eds.), 1969. Slavery in the New World: A Reader in Comparative History. Englewood Cliffs NJ: Prentice-Hall.

FREDERICKSON, GEORGE M., 1981. White Supremacy: A Comparative Study in American and South African History. New York: Oxford University Press.

GEMERY, HENRY A. \& JAN S. HOGENDORN (eds.), 1979. The Uncommon Market: Essays in the Economic History of the Atlantic Slave Trade. New York: Academic Press.

GonsAlves De Mello, José ANTONIO, 2001. Nederlanders in Brazilië (1624-1654): De invloed van de Hollandse bezetting op het leven en de cultuur in Noord-Brazilië. Zutphen, the Netherlands: Walburg Pers. [Orig. 1947.]

GOOR, J. VAN, 1994. De Nederlandse Koloniën: Geschiedenis van de Nederlandse Expansie, 1600-1975. Bilthoven, the Netherlands: SDU Uitgevers.

Goslinga, CoRnelis CH., 1971. The Dutch in the Caribbean and on the Wild Coast, 1580-1680. Gainesville: University of Florida Press.

-, 1985. The Dutch in the Caribbean and in the Guianas, 1680-1791. Assen, the Netherlands: Van Gorcum.

-, 1990. The Dutch in the Caribbean and in Surinam, 1791/5-1942. Assen, the Netherlands: Van Gorcum.

HanNA, Willard A., 1978. Indonesian Banda: Colonialism and its Aftermath in the Nutmeg Islands. Philadelphia: Institute for the Study of Human Issues.

HARRIS, LESLIE M., 2003. In the Shadow of Slavery: African Americans in New York City, 1626-1863. Chicago: University of Chicago Press.

HATFIELD, APRIL LEE, 2003. Atlantic Virginia: Intercolonial Relations in the Seventeenth Century. Philadelphia: University of Pennsylvania Press.

HEIJER, HENK DEN, 1997. Goud, ivoor en slaven: Scheepvaart en handel van de Tweede Westindische Compagnie op Afrika, 1674-1740. Zutphen, the Netherlands: Walburg Pers.

-, 2003. The West African Trade of the Dutch West India Company, 1674-1740. In Johannes Postma \& Victor Enthoven (eds.), Riches from Atlantic Commerce: Dutch Transatlantic Trade and Shipping, 1585-1817. Leiden, the Netherlands: Brill, pp. $138-69$.

- (ed.), 2006. Expeditie naar de Goudkust: Het journaal van Jan Dircksz Lam over de Nederlandse aanval op Elmina, 1624-1626. Zutphen, the Netherlands: Walburg Pers.

HeYwood, Linda M. \& JOHn K. THORnTON, 2007. Central Africans, Atlantic Creoles, and the Foundation of the Americas, 1585-1660. Cambridge: Cambridge University Press.

HOETINK, HARRY, 1967. The Two Variants in Caribbean Race Relations: A Contribution to the Sociology of Segmented Societies. London: Oxford University Press. 
Hoogbergen, Wim, 1992. 'De Bosnegers Zijn Gekomen!' Slavernij en Rebellie in Suriname. Amsterdam: Prometheus.

ISRAEL, JONATHAN \& STUART B. SCHWARTZ, 2007. The Expansion of Tolerance: Religion in Dutch Brazil (1624-1654). Amsterdam: Amsterdam University Press.

JACOBS, JAAP, 1999. Een zegenrijk gewest: Nieuw-Nederland in de zeventiende eeuw. Amsterdam: Bert Bakker.

JONGE, J.K.J. DE, 1862. De opkomst van het Nederlandsch gezag in Oost-Indië, deel I. The Hague: Martinus Nijhoff.

—, 1865. De opkomst van het Nederlandsch gezag in Oost-Indië, deel III. The Hague: Martinus Nijhoff.

JORDAAN, HAN, 1997. De eerste slaven op Aruba: Het plantage-experiment van 1715. In Luc Alofs et al. (eds.), Arubaans akkoord: Opstellen over Aruba van vóór de komst van de olie-industrie. Bloemendaal, the Netherlands: Stichting Libri Antilliani, pp. 117-26.

—, 1999. De veranderende situatie op de Curaçaose slavenmarkt en de mislukte slavenopstand op de plantage Santa Maria in 1716. In Henry A. Coomans et al.(eds.), Veranderend Curaçao. Bloemendaal, the Netherlands: Stichting Libri Antilliani, pp. 473-501.

-, 2003. The Curaçao Slave Market: From Asiento Trade to Free Trade, 1700-1730. In Johannes Postma \& Victor Enthoven (eds.), Riches from Atlantic Commerce: Dutch Transatlantic Trade and Shipping, 1585-1817. Leiden, the Netherlands: Brill, pp. 219-57.

KeSSEL, InEKE VAN (ed.), 2002. Merchants, Missionaries and Migrants: 300 Years of Dutch-Ghanaian Relations. Amsterdam: KIT Publishers.

KETELAARS, A.P.M., 1985. Van inheemse stapelmarkt tot tweederangs koloniale stad: Een geschiedenis van Malakka van 1403 tot omstreeks 1690. Ph.D. dissertation, University of Utrecht, the Netherlands.

Klein, Herbert, 2004. The Atlantic Slave Trade to 1650. In Stuart B. Schwartz (ed.), Tropical Babylons: Sugar and the Making of the Atlantic World, 1450-1680. Chapel Hill: University of North Carolina Press, pp. 201-36.

KLOOSTER, WIM, 1994. Subordinate But Proud: Curaçao's Free Blacks and Mulattoes in the Eighteenth Century. New West Indian Guide 68:283-300.

—, 1997. Slavenvaart op Spaanse kusten: De Nederlandse slavenhandel met Spaans Amerika, 1648-1701. Tijdschrift voor Zeegeschiedenis 16:421-40.

-, 1998. Illicit Riches: Dutch Trade in the Caribbean, 1648-1795. Leiden: KITLV Press.

—, 1999. Van zoutwaterslaven tot Creolen: Curaçao's zwarten en mulatten ten tijde van de West-Indische Compagnie. In Henry E. Coomans et al. (eds.), Veranderend Curaçao. Bloemendaal, the Netherlands: Stichting Libri Antilliani, pp. 505-15.

KNAAP, GERRIT J., 1981. Europeans, Mestizos and Slaves: The Population of Colombo at the End of the Seventeenth Century. Itinerario 5:84-102. 
—, 1991. A City of Migrants: Kota Ambon at the End of the Seventeenth Century. Indonesia 51:105-28.

—, 1995. Slavery and the Dutch in Southeast Asia. In Gert Oostindie (ed.), Fifty Years Later: Antislavery, Capitalism and Modernity in the Dutch Orbit. Leiden: KITLV Press, pp. 193-206.

— \& HEATHER SUTHERLAND, 2004. Monsoon Traders: Ships, Skippers and Commodities in Eighteenth-Century Makassar. Leiden: KITLV Press.

Kolchin, Peter, 1987. Unfree Labor: American Slavery and Russian Serfdom. Cambridge MA: Harvard University Press.

KOOlHof, SiRTJO \& ROBERT Ross, 2005. Upas, September and the Bugis at the Cape of Good Hope: The Context of a Slave's Letter. Archipel 70:281-308.

KRAAN, A. VAN DER, 1983. Bali: Slavery and Slave Trade. In Anthony Reid (ed.), Slavery, Bondage and Dependency in Southeast Asia. St. Lucia, Australia: University of Queensland Press, pp. 315-40.

LIER, R.A.J. VAN, 1977. Samenleving in een grensgebied: Een sociaalhistorische studie van Suriname. Amsterdam: S. Emmering. [Orig. 1949.]

Loth, Vincent C., 1995. Pioneers and Perkeniers: The Banda Islands in the $17^{\text {th }}$ Century. Cakalele 6:13-35.

MCCUSKeR, JOHN J. \& RUSSELl R. MEnARD, 2004. The Sugar Industry in the Seventeenth Century: A New Perspective on the Barbadian "Sugar Revolution." In Stuart B. Schwartz (ed.), Tropical Babylons: Sugar and the Making of the Atlantic World, 1450-1680. Chapel Hill: University of North Carolina Press, pp. 289-330.

MINTZ, SIDNEY W., 1985. Sweetness and Power: The Place of Sugar in Modern History. New York: Viking.

— \& RICHARD PRICE, 1992. The Birth of African-American Culture: An Anthropological Perspective. Boston: Beacon Press. [Orig. 1976.]

MORGAN, PHILIP, 1998. Slave Counterpoint: Black Culture in the Eighteenth-Century Chesapeake and Lowcountry. Chapel Hill: University of North Carolina Press.

MOUTOUKIAS, ZACARÍAS, 1988. Contrabando y control colonial en el siglo XVII: Buenos Aires, el Atlántico y el espacio Peruano. Buenos Aires: Centro Editor de Amerícana Latina.

NASH, GARY B., 1995. The Hidden History of Mestizo America. The Journal of American History 82:941-64.

NIEMEIJER, HENDRIK E., 2000. Slavery, Ethnicity and the Economic Independence of Women in Seventeenth-Century Batavia. In Barbara Watson Andaya (ed.), Other Pasts: Gender and History in Early Modern Southeast Asia. Honolulu: University of Hawai'i Press, pp. 174-94. 
Oest, ERIC Willem VAN DER, 2003. The Forgotten Colonies of Essequibo and Demerara, 1700-1814. In Johannes Postma \& Victor Enthoven (eds.), Riches from Atlantic Commerce: Dutch Transatlantic Trade and Shipping, 1585-1817. Leiden, the Netherlands: Brill, pp. 323-61.

OOSTINDIE, GERT, 2000. Het paradijs overzee: De "Nederlandse" Caraïben en Nederland. Leiden, the Netherlands: KITLV Uitgeverij.

—, 2003. Squaring the Circle: Commemorating the VOC after 400 Years. Bijdragen tot de Taal-, Land-en Volkenkunde 159:135-61.

—, 2008. Slavernij, canon en trauma: Debatten en dilemma's. Tijdschrift voor Geschiedenis 121:4-21.

- (ed.), 1995. Fifty Years Later: Antislavery, Capitalism and Modernity in the Dutch Orbit. Leiden, the Netherlands: KITLV Press.

- (ed.), 1999. Het verleden onder ogen: Herdenking van de slavernij. The Hague: Arena.

— \& EMY MADURO, 1986. In het land van de overheerser II: Antillianen en Surinamers in Nederland, 1634/1667-1954. Dordrecht, the Netherlands: Foris.

PAESIE, RUUD, 2008. Lorrendrayen op Africa: De illegale goederen- en slavenhandel op West-Afrika tijdens het achttiende-eeuwse handelsmonopolie van de West-Indische Compagnie, 1700-1734. Amsterdam: De Bataafsche Leeuw.

PEABODY, SUE, 1997. There are No Slaves in France: The Political Culture of Race and Slavery in the Ancien Régime. New York: Oxford University Press.

PÉTRÉ-GRENOUILLEAU, OLIVIER, 2004. Les traits négrières, ou les limites d'une lecture européocentrique. Revue d'Histoire Moderne et Contemporaine 52(4):30-45.

Postma, Johannes M., 1990. The Dutch in the Atlantic Slave Trade, 1600-1815. Cambridge: Cambridge University Press.

—, 2003a. A Reassessment of the Dutch Atlantic Slave Trade. In Johannes Postma \& Victor Enthoven (eds.), Riches from Atlantic Commerce: Dutch Transatlantic Trade and Shipping, 1585-1817. Leiden, the Netherlands: Brill, pp. 115-38.

—, 2003b. Suriname and its Atlantic Connections, 1667-1795. In Johannes Postma \& Victor Enthoven (eds.), Riches from Atlantic Commerce: Dutch Transatlantic Trade and Shipping, 1585-1817. Leiden, the Netherlands: Brill, pp. 287-322.

PRICE, RICHARD, 2006. On the Miracle of Creolization. In Kelvin A. Yelvington (ed.), Afro-Atlantic Dialogues: Anthropology in the Diaspora. Santa Fe NM: SAR Press, pp. 113-45.

RABEN, REMCO, 2008. Cities and the Slave Trade in Early-Modern Southeast Asia. In Peter Boomgaard, Dick Kooiman \& Henk Schulte Nordholt (eds.), Linking Destinies: Trade, Towns and Kin in Asian History. Leiden, the Netherlands: KITLV Press, pp.119-40. 
Ratelband, KLAAS, 2000. Nederlanders in West-Afrika, 1600-1650: Angola, Kongo en São Tomé. Zutphen, the Netherlands: Walburg Pers.

- (ed.), 1953. Vijf dagregisters van het kasteel São Jorge da Mina (Elmina) aan de Goudkust (1645-1647). The Hague: Martinus Nijhoff.

REDIKER, MARKUS, 2007. The Slave Ship: A Human History. New York: Viking.

ReID, Anthony (ed.), 1983. Slavery, Bondage and Dependency in Southeast Asia. St. Lucia, Australia: University of Queensland Press.

RoOS, DOEKE, 1992. Zeeuwen en de Westindische Compagnie (1621-1674). Hulst, the Netherlands: Van Geyt.

RUPERT, LINDA M., 2006. Inter-Imperial Trade and Local Identity: Curaçao in the Colonial Atlantic World. Ph.D. dissertation, Duke University, Durham NC.

Schama, Simon, 1987. The Embarrassment of Riches: An Interpretation of Dutch Culture in the Golden Age. New York: Knopf.

SCHWARTZ, STUART B. \& JohanNes Postma, 2003. The Dutch Republic and Brazil as Commercial Partners on the West African Coast during the Eighteenth Century. In Johannes Postma \& Victor Enthoven (eds.), Riches from Atlantic Commerce: Dutch Transatlantic Trade and Shipping, 1585-1817. Leiden, the Netherlands: Brill, pp. 171-99.

Singh, ANJANA, 2007. Fort Cochin in Kerala, 1750-1830: The Social Condition of a Dutch Community in an Indian Milieu. Ph.D. dissertation, Leiden University, the Netherlands.

SLUITER, ENGEL, 1997. New Light on the "20 and Odd Negroes" Arriving in Virginia, August 1619. William and Mary Quarterly 54:395-98.

STIPRIAAN, AlEX VAN, 1993. Surinaams contrast: Roofbouw en overleven in een Caraïbische plantagekolonie, 1750-1863. Leiden: KITLV Press.

—, 1995. Debunking Debts: Image and Reality of a Colonial Crisis: Suriname at the End of the Eighteenth Century. Itinerario 19:69-84.

— \& ELLEN BAL, 2002. De VOC is een geloof: Kanttekeningen bij een populair Nederlands imago. In Manon van der Heijden \& Paul van de Laar (eds.), Rotterdammers en de VOC: Handelscompagnie, stad en burgers (1600-1800). Amsterdam: Wrappers, pp. 213-43

STOWE, HARRIET BEECHER, 1852. Uncle Tom's Cabin, or Life Among the Lowly. Boston: John P. Jewett \& Company.

SUTHERLAND, HEATHER, 1983. Slavery and the Slave Trade in South Sulawesi, 1660s1800s. In Anthony Reid (ed.), Slavery, Bondage and Dependency in Southeast Asia. St. Lucia, Australia: University of Queensland Press, pp. 263-85.

TANNENBAUM, FRANK, 1947. Slave and Citizen: The Negro in the Americas. New York: Alfred E. Knopf. 
TERPSTRA, H. (ed,), 1955. Itinerario: Voyage ofte schipvaert van Jan Huygen van Linschoten naer Oost ofte Portugaels Indien, 1579-1592. The Hague: Martinus Nijhoff.

THORTON, JOHN K., 1998. The African Experience of the "20 and Odd Negroes" Arriving in Virginia in 1619. William and Mary Quarterly 55:421-34.

VEEN, ERnST VAN, 1996. How the Dutch Ran a Seventeenth-Century Colony: The Occupation and Loss of Formosa, 1624-1662. Itinerario 20(1):59-77.

VINK, MARKUS P.M., 2003. "The World's Oldest Trade": Dutch Slavery and Slave Trade in the Indian Ocean in the Seventeenth Century. Journal of World History 14(2):131-77.

ViOTTI DA COSTA, EMILIA, 1994. Crowns of Glory, Tears of Blood: The Demerara Slave Rebellion of 1823. New York: Oxford University Press.

Vos, Jelmer, DAVID ElTis \& DAVID RICHARDSON, forthcoming. The Dutch in the Atlantic World: New Perspectives from the Slave Trade with Particular Reference to the African Origins of the Traffic. In David Eltis \& David Richardson (eds.), Extending the Frontiers: Essays on the New Transatlantic Slave Trade Database. New Haven CT: Yale University Press,.

WALLE, AN VAN DE, 2001."Soete dieren en stinkende swartinnen": Beeldvorming en representatie van de Oost-Indische vrouw in de Nederlandse reisliteratuur. In Jan Parmentier \& Sander Spanoghe (eds.), Orbis in orbem: Liber amoricum John Everaert. Gent, Belgium: Academia Press, pp. 475-502.

WÄTtJen, HermanN, 1921. Das Hollandische Kolonialreich in Brasilien: Ein Kapitel aus der Kolonialgeschichte des 17. Jahrhunderts. Gotha, Germany: F.A. Perthes.

WELIE, RIK VAN, forthcoming. Slavery and Slave Trade in the Dutch Colonial World. In Gert Oostindie (ed.), Migrations and Cultural Heritage in the Dutch Colonial World. Leiden, the Netherlands: KITLV Press.

WOLFF, MARIANNE, 1992. Cochin: Een mestiese samenleving in India. M.A. thesis, Leiden University, the Netherlands.

RIK VAN WELIE

Department of History

Emory University

Atlanta GA, 30322 U.S.A.

<rikvanwelie@hotmail.com> 